North Carolina State Library Raleigh

NORTH CAROLINA

DEPARTMENT OF CONSERVATION AND DEVELOPMENT

WILLIAM P. SAunders, Director

DIVISION OF MINERAL RESOURCES

JASPER L. STUCKEY, State Geologist

BULLETIN NUMBER 70

\title{
UPPER CRETACEOUS OSTRACODA FROM NORTH CAROLINA
}

\author{
By \\ PHILIP MONROE BROWN \\ Geologist, United States Geological Survey
}

PREPARED COOPERATIVELY BY THE GEOLOGICAL SURVEY, UNITED STATES DEPARTMENT OF THE INTERIOR 

North Cardina State Library

Raleigh

$\stackrel{N}{S_{\infty C}} \mathrm{C}$

NORTH CAROLINA

DEPARTMENT OF CONSERVATION AND DEVELOPMENT

WILLIAM P. SAUNDERS, Director

DIVISION OF MINERAL RESOURCES

JASPER L. STUCKEY, State Geologist

BULLETIN NUMBER 70

\title{
UPPER CRETACEOUS OSTRACODA FROM NORTH CAROLINA
}

\author{
By \\ PHILIP MONROE BROWN \\ Geologist, United States Geological Survey
}

PREPARED COOPERATIVELY BY THE GEOLOGICAL SURVEY, UNITED STATES DEPARTMENT OF THE INTERIOR 
LETTER OF TRANSMITTAL

Raleigh, North Carolina

April 30, 1957

To His Excellency, HONORABLE LUTHER H. HODGES

Governor of North Carolina

Sir :

I have the honor to submit herewith manuscript for publication as Bulletin No. 70, "Upper Cretaceous Ostracoda from North Carolina," by Philip M. Brown.

This report is a product of the program on ground-water investigation being carried out by the Department of Conservation and Development in cooperation with the United States Geological Survey. It contains information that should be of value in the interpretation of the geology, groundwater resources, and potential mineral deposits of the Upper Cretaceous formations of North Carolina.

Respectfully submitted,

WILLIAM P. SAUNDERS

Director 
Digitized by the Internet Archive in 2013

http://archive.org/details/uppercretaceouso1957brow 


\title{
UPPER CRETACEOUS OSTRACODA FROM NORTH CAROLINA
}

\author{
By \\ PhILIP MONROE BROWN ${ }^{1}$
}

\begin{abstract}
Fifty-six species of Upper Cretaceous Ostracoda from ten exposures in North Carolina and one exposure in South Carolina are described and illustrated. Twenty-seven of the species are new. The following genera, one of which is new, are represented in the material: Cytherella Jones, Cytherelloidea Alexander, Bairdia McCoy, Bairdoppilata Coryell, Sample, and Jennings, Cytheridea (Haplocytheridea) Stephenson, Cytheridea (Clithrocytheridea) Stephenson, Alatacythere Murray and Hussey, Brachycythere Alexander, Trachyleberis Brady, Platycythereis Triebel, Protocythere Triebel, Progonocythere Sylvester-Bradley, Cytheropteron (Cytheropteron) Sars, Cytheropteron (Eocytheropteron) Alexander, Velarocythere Brown, Cytherideis Jones, Monoceratina Roth, Loxoconcha Sars, Orthonotacythere Alexander, Cytherura Sars, and Eucytherura Müller. A checklist showing relative abundance of specimens in outcrop and denoting the occurrence of species in strata penetrated by water wells is included.
\end{abstract}

${ }^{1}$ Geologist, Ground Water Branch, U. S. Geological Survey, Raleigh, N. C.

\section{Introduction}

This paper is a result of studies undertaken to establish paleontologic control for the subsurface separation of the Upper Cretaceous Black Creek and Peedee formations in the North Carolina Coastal Plain. Ground-water investigations had shown the two formations to be major aquifers and distinct hydrologic units, but their lithologic similarity precludes their visual separation in well cuttings. The Ostracoda were chosen as the paleontologic control because of their apparent tolerance to variable environmental changes, resulting in a wide distribution of species in variable lithofacies over relatively wide geographic areas. All species described in this paper are from outcrops of Cretaceous sediments. A checklist (fig. 2) notes species that have been recognized in well cuttings. Information relative to the occurrence of the species in the subsurface is taken from a report by the writer entitled, "Well logs from the North Carolina Coastal Plain," which is to be published by the Division of Mineral Resources of the North Carolina Department of Conservation and Development after the publication of this report.

This investigation was made by the United States Geological Survey in financial cooperation with the North Carolina Division of Mineral Resources. The work was done under the general supervision of A. N. Sayre, Chief, Ground Water Branch, U. S. Geological Survey, and J. L. Stuckey, State Geologist of North Carolina, and under the immediate supervision of $\mathrm{H}$. E. LeGrand, district geologist of the Ground Water Branch for North Carolina. 


\section{Acknowledgments}

Appreciation is expressed to Mr. H. E. LeGrand who has given freely of his time and of his extensive knowledge of the Cretaceous deposits of the Atlantic Coastal Plain, and who has encouraged the writer to undertake this problem. Dr. Landis Bennett, Visual Aids Department, North Carolina State College, acted as technical advisor on photography. Professor F. M. Swain, University of Minnesota, Professor Walter Wheeler, University of North Carolina, and Mr. I. G. Sohn, U. S. Geological Survey, offered many helpful suggestions during the preparation of the manuscript.

\section{Previous Work}

The only previous work dealing with Mesozoic Ostracoda in North Carolina is that of Swain (1952), who described and illustrated 47 species from two deep oil tests in the State. Other sources containing information concerning Mesozoic Ostracoda from the Atlantic Coastal Plain are papers by Berry (1925), Coryell and others (1935), Jennings (1936), Schmidt (1948), and Swain (1948). Mesozoic Ostracoda from Upper Cretaceous equivalents of the Gulf Coastal Plain have been the subject of a more intensive study.

\section{Stratigraphy}

As presently recognized, the outcropping Upper Cretaceous formations of the North Carolina Coastal Plain are, in ascending order, the Tuscaloosa, Black Creek, and Peedee formations. According to present information, the Tuscaloosa formation contains no marine fossils in outcrop, but beds mapped as the Tuscaloosa formation in the subsurface contain a fauna of Eagle Ford and Woodbine age (Spangler, p. 116). The Tuscaloosa formation is unconformably overlain by the Black Creek formation. The Black Creek formation consists of a lower, unnamed member and an upper member, the Snow Hill marl member. On the basis of lithology and stratigraphic position, the lower member of the Black Creek formation at the surface is considered to be the shoreward extension of beds equivalent to those of Austin or Taylor age in the subsurface. The upper member, the Snow Hill marl member, is of Taylor age, the correlation being based on the presence of Exogyra ponderosa in outcropping sections (Stephenson, 1923 , p. 48). The Peedee formation overlies the Black Creek formation conformably. In North Carolina the Peedee formation includes the $E x$ ogyra costata zone and the Exogyra cancellata subzone of Stephenson and is correlated with the Navarro formation and its equivalents of the Gulf Coast (Stephenson, 1923, p. 51).

The fauna described in this paper was obtained from exposures of the Snow Hill marl member of the Black Creek formation and from the Peedee formation. Zonation of the two units by means of the ostracodes seems practical but was not undertaken at this time because the subsurface hydrologic boundaries, which the writer was seeking to establish, are formational rather than intraformational in nature.

\section{Lithologic Character of Snow Hill Marl Member of Black Creek Formation and Peedee Formation}

In surface exposures the Snow Hill marl member consists of black to gray laminated sandy clay and interbedded sand, with varying amounts of fine-grained glauconite, marcasite aggregates, and black lignitized wood fragments. Most of the macrofossils consist of poorly preserved casts and molds, no calcareous shell material remaining. Locally, however, calcareous shell material has been preserved in a sandy clay matrix, and forms a drab-gray marl which reflects varying degrees of induration. The Peedee formation exhibits a variable lithology in outcrop. In the southern part of the State it most nearly resembles the Snow Hill marl member lithologically, and it is very difficult to separate the two even where they occur in the same section. Along the strike to the northeast, in Lenoir, Pitt, and Greene Counties, the Peedee is composed of gray to green medium- to coarsegrained glauconitic sand in a clay matrix containing varying amounts of calcareous shell material. Indurated beds composed mainly of the valves of Exogyra costata Say and Exogyra cancellata Stephenson form prominent ledges along many of the streams. 


\section{Collecting Localities}

Localities from which ostracodes were obtained are shown on the accompanying map, figure 1 . The locality designated as the type locality for the Snow Hill marl member was described by Kerr, in 1875, as being at Snow Hill along Contentnea Creek. This was the locality from which Conrad, in 1871, collected and described numerous fossils. However, there are no good exposures of fossiliferous material along the stream at Snow Hill. The writer has walked out a considerable section of the stream during periods of extremely low flow, and the first section that contains any identifiable fossils is 1.7 miles downstream from the town of Snow Hill. This section, consisting of prominent bluffs along both sides of the creek, contains a drab-gray to black shell marl as much as eight feet thick which is exposed intermittently along both sides of the stream for several miles. This locality generally conforms with Kerr's description of the marl beds along Contentnea Creek at Snow Hill. Therefore, for the purpose of this paper, and as a matter of record, locality J, 1.7 miles downstream from the town of Snow Hill, is designated as the reference locality of the Snow Hill marl member of the Black Creek formation.

(Thickness of exposed sections varies, as it is dependent upon seasonal water levels in bordering streams).

\section{Outcrops of the Peedee formation}

Locality A-Scuffleton, Pitt County, N. C., on the farm of E. H. Rogers, 0.7 mile north of Scuffleton on N. C. Route 102, about 16 feet of the Peedee formation occurs in a bluff on the east bank of Little Contentnea Creek. The following section of the Peedee was observed by the writer: Feet

1 Indurated shell bed, composed mainly of the valves of Exogyra costata. Ostracoda and Foraminifera common.

4 Grayish-green poorly-sorted glauconitic sand, partially indurated. Ostracoda and Foraminifera common.

8 Drab-gray arenaceous, micaceous clay, sparsely glauconitic. Ostracoda and Foraminifera abundant.

1 Indurated shell bed, conglomeratic; valves of Exogyra costata and Exogyra cancellata predominate. Ostracoda and Foraminifera rare.
2 Black marl; lignitized wood fragments prominent. Ostracoda and Foraminifera abundant.

Locality B-Bladen County, N. C., Cape Fear River. On the west bank of the Cape Fear River 100 feet downstream from the bridge crossing, which is $1 \frac{1}{2}$ airline miles downstream from U. S. Lock No. 1 at Kings Bluff, the following section of the Peedee was sampled by H. E. LeGrand and the writer:

Feet

1 Gray indurated shell bed composed of the valves of Exogyra costata. Ostracoda and Foraminifera very rare.

3 Black waxy arenaceous clay containing numerous broken shell fragments. Ostracoda and Foraminifera abundant.

1 Gray indurated shell bed extending to river level. No recovery of microfossils.

Locality C-Kinston, Lenoir County, N. C., Neuse River. On the north bank of the Neuse River 0.54 mile west of Kinston on U. S. Route 70 and opposite the Caswell Training School, the following section of the Peedee was observed by H. E. LeGrand and the writer:

Feet

2 Grayish-green glauconitic sand and clay, partially indurated. Ostracoda and Foraminifera common.

5 Drab-gray to black arenaceous clay containing abundant shells and shell fragments. Ostracoda and Foraminifera abundant.

2 Gray indurated shell bed. Ostracoda and Foraminifera common.

Locality D-Wilmington, New Hanover County, N. C., Northeast Cape Fear River. At Hilton Park in Wilmington at a point on the east bank of the river at the Wilmington Waterworks plant, the following section of the Peedee was observed by H. E. LeGrand and the writer:

Feet

12 Gray glauconitic, micaceous clays; massive in the upper third, becoming more arenaceous in the middle and lower thirds. Brcken shell fragments prominent, partially indurated near the base which is covered at high tide. Ostracoda and Foraminifera common to rare. 


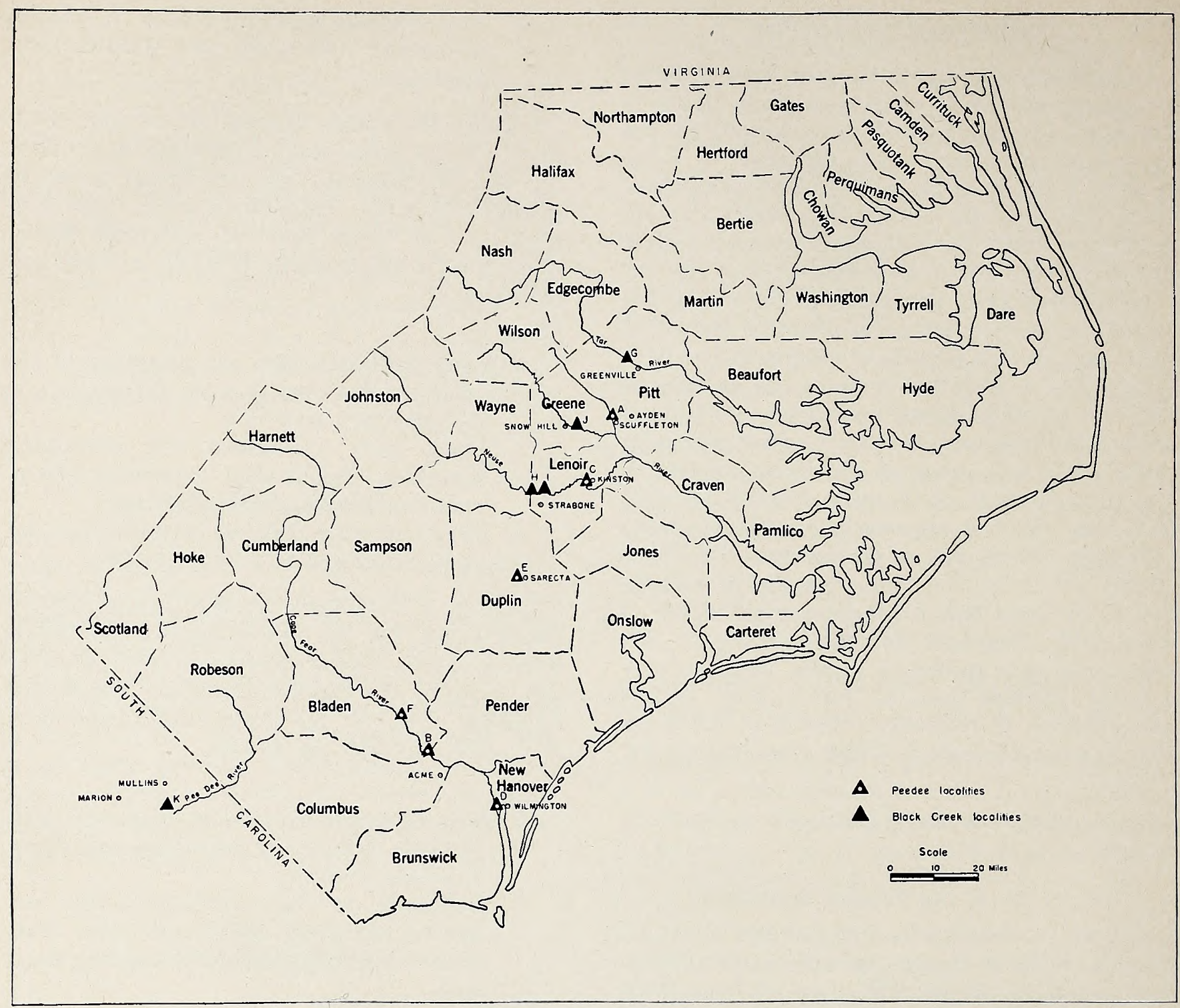

Figure 1.-Upper Cretaceous localities from which Ostracoda are listed. 
Locality E-Sarecta, Duplin County, N. C. In the north side of a roadcut, one-fourth mile west of Sarecta and 400 yards east of the bridge across the Northeast Cape Fear River, the following section of the Peedee was observed by H. E. LeGrand and the writer:

Feet

7 Drab-black to gray arenaceous clays containing many fine shell fragments and sharks teeth. Ostracoda and Foraminifera abundant.

Locality F-Carvers, Bladen County, N. C., Cape Fear River. On the Walter Johnson farm, west bank of the Cape Fear River between mileposts 48 and 49 , the following section of the Peedee was observed by H. E. LeGrand and the writer in a steep ravine in front of the farm house, an estimated 15 feet above normal river level:

Feet

11. Drab-black to gray massive clays, more arenaceous in the upper third. Ostracoda and Foraminifera abundant.

2 Interbedded sands and clays, partially indurated. Exogyra costata common, broken shell fragments abundant. Ostracoda and Foraminifera common.

\section{Outcrops of the Snow Hill marl member of the Black Creek formation}

Locality G-Greenville, Pitt County, N. C., Tar River, U.S.G.S. locality nos. 4144 and 5347. At Blue Banks Landing on the south bank of the Tar River seven miles upstream from Greenville, the following section of the Black Creek was observed in a steep bluff by H. E. LeGrand and the writer:

Feet

16 Grayish-green to black micaceous, arenaceous, laminated clays. Lignitized wood and plant remains prominent. The lower two feet of the section approaches a marl, containing Exogyra ponderosa and many large shells. Ostracoda and Foraminifera in the upper third of the section are generally recrystallized with small globules of pure calcite affixed to the shells. Ostracoda in the lower two-thirds of the section are abundant. Foraminifera are less common.

Locality H-Lenoir County, N. C., Neuse River, U.S.G.S. locality nos. 4160 and 5353. At Auger Hole Landing, milepost $73,0.5$ mile downstream from the Wayne County line, on the north bank of the Neuse River the following section of the Black Creek was observed by H. E. LeGrand and the writer:

Feet

7 Dark-gray to black interbedded, lenticular sands and clays, slightly indurated at the base. Macrofossils consist of poorly preserved casts and molds. No microfossils were recovered from the exposed section. Ostracoda listed from this locality were obtained from a 15 foot auger hole sample. The auger hole was located 100 feet from the river bank.

Locality I-Strabane, Lenoir County, N. C., Neuse River. At One Dram Landing, 0.2 mile downstream from the mouth of Bear Creek, on the north bank of the Neuse River, one-half mile upstream from the bridge, which is 1.7 miles north of Strabane, N. C., the following section of the Black Creek was observed by H. E. LeGrand and the writer:

Feet

3 Black clay-marl with thin interbedded sandy layers, finely glauconitic. No microfossils.

2 Indurated shell bed projecting out into the river about 15 feet. No microfossils. The Ostracoda listed from this locality were obtained from a 9-foot auger hole sample. The auger hole was located 25 feet from the river bank.

Locality J-Snow Hill, Greene County, N. C., Contentnea Creek. On the farm of L. C. Daniels, 1.7 miles downstream from Snow Hill, N. C., the following section of the Black Creek was observed by the writer on the east bank of Contentnea Creek:

Feet

1.5 Rusty, iron-stained coarse sand, partially indurated and containing fossils as casts and molds. No microfossils.

8 Gray to black clay-marl containing abundant but fragile macrofossils. Exogyra ponderosa is in the lower five feet of this interval. Ostracoda and Foraminifera common in the lower three feet of this interval.

Locality K-Mullins, Marion County, S. C., Pee Dee River tributary, U.S.G.S. locality no. 5372. Three miles south-southeast of Mullins at an old 
mill site known as Hodges Mill on the west bank of an unnamed tributary of the Pee Dee River the following section of the Black Creek was observed by $H$. E. LeGrand and the writer:

Feet

3 Black-thinly laminated interbedded sand and clay. No microfossils.

4 Black clay-marl containing numerous broken shell fragments. Ostracoda and Foraminifera rare.

\section{Systematic Descriptions}

$\begin{array}{lll}\text { Order } & \text { Ostracoda } & \text { Latreille, } 1802 \\ \text { Suborder } & \text { Platycopa } & \text { Sars, } 1866 \\ \text { Family } & \text { Cytherellidae } & \text { Sars, } 1866 \\ \text { Genus } & \text { Cytherella } & \text { Jones, } 1849\end{array}$

\section{Cytherella bullata Alexander}

Plate 1, Figures 6, 7

Cytherella obesa Alexander, 1929, Texas Univ. Bull. 2907, p. 51, pl. 1, figs. 3, 6 .

(Non. Cytherella obesa Jones, Kirkby, and Brady, 1884)

Cytherella austinensis Alexander, 1929, Texas Univ. Bull. 2907, p. 51, pl. 2, figs. 4, 6.

Cytherella bullata Alexander, 1931, Jour. Paleontology, vol. 6, p. 101. Alexander, 1932, Amer. Mid. Naturalist, vol. 13 , no. 5, p. 305 , pl. 28 , figs. $3,4$.

Cytherella cf. C. obesa Alexander. Swain, 1952,

Ostracoda from wells in North Carolina, Pt. 2,

Mesozoic Ostracoda: U. S. Geol. Survey Prof.

Paper 234-B, p. 68, pl. 8, fig. 2.

Shell subovate in lateral view; greatest height median; dorsal margin convex; ventral margin weakly convex; anterior margin broadly rounded, slightly compressed; posterior margin less broadly rounded. Right valve larger and overlapping around entire margin, least overlap at posterior ventral margin. Surface of right valve smooth. Anterior margin of left valve bears a weak rim more pronounced medially and ventrally, surface otherwise smooth.

Dimensions: Fig. 7: length $0.68 \mathrm{~mm}$; height $0.39 \mathrm{~mm}$; biconvexity $0.21 \mathrm{~mm}$.

Occurrence: Black Creek only, localities G and J. U.S.N.M. 128887, 128888.

\section{Cytherella ovata (Röemer) \\ Plate 1, Figure 12}

Cytherina ovata Röemer, 1840, Verstein norddeutsch. Kreidegeb, p. 104, pl. 16, fig. 21.

Cytherella ovata Jones, 1849, Monogr. Cret. Entomostraca England, Palaeontographical Soc., London, p. 28, pl. 7, figs. 24a-i.

Jones and Hinde, 1890, Suppl. Monogr. Cret. Entomostraca England and Ireland: Palaeontographical Soc., London, p. 44, pl. 3, figs. 48-54. pl. 4, fig. 39.

Cytherella obovata Jones and Hinde, 1890, Suppl. Monogr. Cret. Entomostraca England and Ireland: Palaeontographical Soc., London, p. 46, pl. 3, figs. $46,47$.

Cytherella navarroensis Alexander, 1929, Texas Univ. Bull. 2907, p. 53, pl. 2, figs. 1, 2.

Swain, 1952, Ostracoda from wells in North Carolina, pt. 2, Mesozoic Ostracoda, U. S. Geol. Survey Prof. Paper 234-B, p. 68, pl. 8, fig. 1,

Cytherella moremani Alexander, 1929, Texas Univ. Bull. 2907, p. 53, pl. 1, figs. 4, 5.

Jennings, 1936, Bull. Am. Paleontology, vol. 23, no. 78 , p. 41 , pl. 6 , fig. 1 .

Cytherella ovata (Röemer) Alexander, 1932, Amer. Mid. Naturalist, vol. 13, no. 5, p. 307 , pl. 28, figs. 1, 2.

(Non. C. ovata Alexander, 1929, Texas Univ. Bull. 2907, p. 47, pl. 1, figs. 1, 2)

Dimensions: Fig. 12 : length $0.78 \mathrm{~mm}$; height $0.49 \mathrm{~mm}$; biconvexity $0.32 \mathrm{~mm}$.

Occurrence: Peedee only, localities A, D (?), and F. U.S.N.M. 128889.

Remarks: Swain (1952, p. 68) has recently described the species.

\section{Cytherella tuberculifera Alexander Plate 1, Figures 3-5}

Cytherella tuberculifera Alexander, 1929, Texas Univ. Bull. 2907, p. 52, pl. 2, fig. 3.

Shell subovate-elongate in lateral view; greatest height median; dorsal margin convex, strongest posteriorly; ventral margin very weakly convex; anterior margin strongly rounded, greatest ventrally; posterior margin of left valve smoothly 
rounded, that of right valve strongly rounded and drawn out into median bulbous extension, truncated. Right valve larger and overlapping lefi valve, greatest anteriorly and dorsally. Surface smooth. Internal features not observed.

Dimensions: Fig. 3: length $0.87 \mathrm{~mm}$; height $0.44 \mathrm{~mm}$; biconvexity $0.33 \mathrm{~mm}$.

Occurrence: Peedee only, localities A and E. U.S.N.M. $128890,128891,128892$.

Remarks: The bulbous posterior extension of the right valve serves to readily distinguish this species.

\section{Cytherella herricki Brown, n. sp. Plate 1, Figures 8-11}

Shell subovate-elongate in lateral view; greatest height slightly anterad of median; dorsal margin moderately convex; ventral margin straight; anterior margin broadly and evenly rounded; posterior margin rounded. Right valve larger than left, overlapping around entire periphery, greatest anterad dorsally.

Surface finely punctate, coarser medially, with a faint "crescent-shaped" median sulcus extending from just inside dorsal margin to center of valve; anterior margin of left valve bears a fine sharp rim below, more pronounced medially. Interior of valves deep posteriorly and showing a smooth ridge marking position of median sulcus, otherwise smooth.

Dimensions : Holotype : length $0.74 \mathrm{~mm}$; height $0.42 \mathrm{~mm}$; biconvexity $0.25 \mathrm{~mm}$.

Occurrence: Peedee only, localities A, C, and F. U.S.N.M. 128893, 128894, 128895, 128896.

Remarks: The punctate surface and median sulcus serves to readily distinguish this species. Specimens which bear a slightly extended and inflated posterior area in the right valve and a very faint anterior swelling ventrally in the left valve probably represent female dimorphs. Named for Dr. Stephen Herrick, U. S. Geological Survey.

\section{Cytherella sp. \\ Plate 1, Figureș 1, 2}

Ovate valves of Cytherella occur frequently in many of the Peedee outcrops. They are generally short in relation to width and contain a faint illdefined depression dorso-medially. No attempt was made to further identify these specimens as no complete carapaces showing overlap relationships were present in the material examined.
Dimensions: Fig. 1: length $0.85 \mathrm{~mm}$; height $0.53 \mathrm{~mm}$; convexity $0.13 \mathrm{~mm}$.

Occurrence: Peedee only, localities A, B, C, D, and E. U.S.N.M. 128897, 128898.

Remarks: Common in subsurface Peedee (upper part).

Genus Cytherelloidea Alexander, 1929 Cytherelloidea swaini Brown, n. sp. Plate 1, Figures 16-19

Shell short, quadrate in side view; dorsal margin slightly convex, sinuous; ventral margin straight; anterior margin broadly rounded; posterior margin more narrowly rounded. Right valve larger and overlapping left, greatest at anterior dorsal angle.

Anterior margin with broad sloping rim and subjacent depression posterad; sharp ventral rim, connected with anterior rim at anterior ventral angle, forms ventral margin passing posterad into large high tubercle located at posterior ventral angle; a second large high tubercle lies at posterior dorsal angle; a bulbous dorsal ridge rises postjacent to and slightly forward of the anterior dorsal angle, curves gently towards the anterior dorsal angle, and forms the dorsal margin passing posterad into the dorsal tubercle. There is a deep subcentral depression. Touching the ventral margin, medially, is a thick bulbous ridge, anterad rising upward and passing into the anterior third of the valve, posterad rising upward and passing into posterior third of valve just short of the ventral tubercle. A short rim along the posterior margin connects dorsal and ventral tubercles. Interior of valves, rugose, deep posteriorly.

Dimensions : Holotype : length $0.58 \mathrm{~mm}$; height $0.36 \mathrm{~mm}$; biconvexity $0.22 \mathrm{~mm}$.

Occurrence: Peedee only, localities A, B, C, D, E, and F. U.S.N.M. 128899, 128900, 128901.

Remarks: This species which can be distinguished by the large posterior tubercles and sloping anterior rim is an excellent guide fossil for the Peedee formation. Named for Professor Frederick M. Swain, University of Minnesota.

Cytherelloidea (?) cuneiforma Brown, n. sp. Plate 1, Figures 13-15

Carapace in lateral view, oblong-subovate; dorsal margin straight, slightly arched in posterior third; ventral margin straight to weakly concave 
medially; anterior margin broadly and evenly rounded, weakly rimmed below; posterior margin less broadly rounded; right valve larger than left around entire periphery, more pronounced dorsally and ventrally; widest post-medially, highest in posterior fourth.

Medially, the valves show a system of clearly defined, closely spaced, wedge-shaped furrows outlined by fine subdued ridges which show a subparallel to anastomosing arrangement; anterior and posterior thirds smooth, surface glassy.

Dimensions: Holotype : length $0.63 \mathrm{~mm}$; height $0.35 \mathrm{~mm}$; biconvexity $0.18 \mathrm{~mm}$.

Occurrence: Peedee only, localities A, C, and F. U.S.N.M. 128902, 128903, 128904.

Remarks: The outline, valve overlap, faint anterior rim and internal features of this species are suggestive of the genera Cytherella Jones and Cytherelloidea Alexander. Because of the median surface sculpture which resembles arachaic wedge-shaped writing the specimens are believed to be closer to Cytherelloidea Alexander and are provisionally placed in that genus.

\section{Cytherelloidea sohni Brown, n. sp. Plate 2, Figures 1-3}

Shell in side view, subquadrate; dorsal margin sinuate, convex medially; ventral margin straight, slightly concave medially; anterior margin broadly rounded; posterior margin rounded.

Anterior, ventral, and posterior margins sharply rimmed by a continuous connecting ridge rising at anterior dorsal angle. At posterior dorsal angle the ridge swings gently inward subparallel to the dorsal margin, terminating below the anterior dorsal angle and outlining, dorsally, a shallow subcentral pit. Between the pit and ventral margin are two short ridges, slightly concave upward, and merging at their ends into the posterior and anterior-third of the valves.

Dimensions : Holotype : length $0.57 \mathrm{~mm}$; height $0.29 \mathrm{~mm}$; biconvexity $0.19 \mathrm{~mm}$.

Occurrence: Peedee only, localities A, C, and F. U.S.N.M. 128905, 128906, 128907.

Remarks: This species which has not been recognized in well cuttings south of the Neuse River seems to be an excellent subsurface guide in the northeastern part of the State. Named for I. Gregory Sohn, U. S. Geological Survey.

\section{Cytherelloidea greenensis Brown, n. sp.}

Plate 1, Figures 22, 23, 26, 29

Carapace in lateral view, oblong-ovate; dorsal margin straight to weakly convex; ventral margin straight; anterior margin broadly and evenly rounded; posterior margin less broadly rounded.

Anterior margin with well-defined rim; ventral margin less strongly rimmed; above posterior margin and parallel to it are prominent well-defined dorsal and ventral tubercles connected by a short sharp ridge; a sharp ridge extends from the ventral tubercle, anteriorly, parallel to and above the ventral margin, terminating sharply in flat anterior third of the carapace; a short ridge, subjacent to the dorsal margin, extends from the dorsal tubercle terminating behind and above a shallow subcentral pit; subcentral pit outlined above by a short sharp ridge parallel to the dorsal margin.

Dimensions: Holotype: length $0.57 \mathrm{~mm}$; height $0.31 \mathrm{~mm}$; biconvexity $0.18 \mathrm{~mm}$.

Occurrence: Peedee cnly, localities A, C, and E. U.S.N.M. 128908, 128909, 128910.

Remarks: The shape, wide-spacing of the posterior tubercles and arrangement of the ridges distinguishes this species from $C$. swaini and $C$. andrewsi, n. sp.'s.

\section{Cytherelloidea andrewsi Brown, n. sp.} Plate 1, Figures 24, 27, 28

Carapace small, subovate in lateral view; dorsal margin gently arched; ventral margin straight, slightly concave medially; anterior margin broadly and evenly rounded; posterior margin more narrowly rounded than anterior. Right valve larger than left, overlap greatest along dorsum.

Marginal rim commencing at antero-dorsal junction follows anterior, ventral and posterior margins, posterad of dorsum, medially, the ridge curves inward and around a deep subcentral pit, becomes slightly sinuous beneath the subcentral pit, and terminates just short of the marginal rim at the postero-dorsal junction; a second prominent ridge, separated from the subcentral pit by a prominent elongate depression, rises in anterior third, parallels the ventral margin and curves upward posteriorly to terminate just short of the posterior rim medially. The subcentral pit contains a weak ridge giving the pit the appearance of being subequally divided.

Dimensions : Holotype : length $0.52 \mathrm{~mm}$; height $0.31 \mathrm{~mm}$; biconvexity $0.20 \mathrm{~mm}$.

Occurrence: Peedee only, localities A, C, and E. U.S.N.M. 128911, 128912, 128913.

Remarks: This species is named for Dr. T. G. 
Andrews former head of the geology department, University of Alabama.

\section{Cytherelloidea inflata Brown, n. sp.} Plate 1, Figures 20, 21, 25

Carapace small, ovate in lateral view; inflated anteriorly, more so posteriorly; dorsal margin weakly arched; ventral margin straight; anterior margin broadly and evenly rounded; posterior margin gently rounded dorsally, angulate ventrally.

Anterior and ventral margins with well developed rims. Posterior fourth, with a steep slope to the posterior margin, is surmounted by ill-defined, weakly connected, dorsal and ventral tubercles; a strong ridge above and parallel to the ventral margin extends from the ventral tubercle anteriorly, and terminates submedially in the anterior third of the carapace. A short ridge extends medially from the dorsal tubercle and terminates just short of a prominent subcentral pit. A second bulbous ridge extends from the dorsal tubercle, extends parallel to and above the dorsal margin, swings inward at the antero-dorsal junction and terminates in inflated anterior third. A short illdefined ridge, extending from the inflated anterior third, outlines the subcentral pit below.

Dimensions : Holotype : length $0.50 \mathrm{~mm}$; height $0.32 \mathrm{~mm}$; biconvexity $0.21 \mathrm{~mm}$.

Occurrence: Peedee only, localities A, C, and E. U.S.N.M. 128914, 128915, 128916.

Remarks: This species bears superficial resemblance to $C$. swaini Brown but can be separated on the basis of its longer and continuous ventral ridge, posterior slope and less well-defined tubercles.

\section{Suborder Podocopa Sars, 1866 Family Bairdiidae Sars, 1888 \\ Genus Bairdia McCoy, 1844 Bairdia pittensis Brown, n. sp. Plate 3, Figures 1-3}

Carapace small, subquadrate in lateral view; highest medially; hinge margin straight medially, broadly obtuse at cardinal angles; ventral margin straight to sinuous; anterior margin obtusely rounded and extended; posterior margin acuminate and extended below. Left valve larger than right, overlapping, greatest overlap along postero-dorsal slope. Surface of valves strongly and finely pitted.
The internal features, showing the lack of hinge denticulations on the dorsal slopes place this species in the genus Bairdia McCoy. The muscle scar consists of a long lateral scar below which are four parallel offset scars two on each side of a circular area and below which is a sixth large scar parallel to the topmost lateral scar. Interior of the valves are coarsely punctate. Inner margin and line of concrescence widely separated at anterior and posterior extremities.

Dimensions : Holotype: length $0.64 \mathrm{~mm}$; height $0.31 \mathrm{~mm}$; biconvexity $0.24 \mathrm{~mm}$. The two valves of the holotype were separated after being measured.

Occurrence: Peedee only, locality A. U.S.N.M. 128917.

Remarks: This species most closely resembles Bairdia fortificata Brady from Tertiary and Recent sediments. It can be separated from that species by its more discretely punctate surface, narrower posterior margin and smaller size. Two complete carapaces and a left valve were the only specimens obtained at the outcrop. However, because of its unique appearance and its occurrence in several wells it has been described and figured.

Genus Bairdoppilata Coryell, Sample, and Jennings, 1935

Bairdoppilata pondera Jennings

Plate 3, Figures 4, 7, 8

Bairdoppilata pondera Jennings, 1936, Bull. Am.

Paleontology, vol. 23, no. 78, p. 45, pl. 6, fig. 9.

Schmidt, 1948, Jour. Paleontology, vol. 22, p. 408, pl. 61, figs. 21, 22.

Swain, 1952, U. S. Geol. Survey Prof. Paper 234-B, p. 71, pl. 8, figs. 8-12.

Dimensions: Fig. 7: length $1.18 \mathrm{~mm}$; height $0.75 \mathrm{~mm}$; biconvexity $0.52 \mathrm{~mm}$.

Occurrence: Peedee only, localities A, E, and F. U.S.N.M. 128918, 128919, 128920.

Remarks: Swain (1952, p. 72) has recently described the species and listed its occurrence in North Carolina well samples as Black Creek and lower. During the present study of outcrop and well samples the species has not been recognized in sediments older than the Peedee formation.

\section{Bairdoppilata postextensa (Swain) Plate 3, Figures 5, 6, 9}

Bairdia postextensa Swain, 1948, Maryland Dept. Geology, Mines and Water Res., Bull. 2, p. 193, pl. 12 , fig. 10 .

Carapace subtriangular in side view; greatest 
height slightly anterad of median; dorsal margin strongly arched; ventral margin convex; anterior margin evenly rounded, slightly extended; posterior margin angulate, obtuse.

Left valve larger and overlaps right valve along all margins, overlap most pronounced mid ventrally. Surface smooth and glassy. Fine denticulations on the selvage along anterior and posterior dorsal slopes. Muscle scars not observed.

Dimensions: Fig. 6: length $1.10 \mathrm{~mm}$; height $0.62 \mathrm{~mm}$; biconvexity $0.43 \mathrm{~mm}$.

Occurrence: Peedee only in outcrop. Swain (1948, p. 193) lists the species from an Eocene interval in the Hammond well. The species has been recognized in water wells from intervals designated as middle and lower Eocene during the present study. Localities A and C. U.S.N.M. 128921, 128922, 128923.

Remarks: This species which occurs with Bairdoppilata pondera Jennings can be most easily distinguished from that species by the larger ratio of length to height and the more pronounced extension of the posterior third of the carapace of $B$. postextensa. Swain (1948, p. 189) lists the species as occurring in the Eocene interval in the Hammond well at a depth of 1320-1330 feet.

\section{Family Cytheridae Baird, 1850}

The family Cytheridae has been subjected to recent revision by Sylvester-Bradley (1948, p. 794). S-Bradley erected the family Trachyleberidae to include the genera Trachyleberis Brady and Platycythereis Triebel-genera that are discussed in this paper. Swain $(1951$, p. 17, 18) and Puri (1953, p. 172, 173) have discussed the revision and questioned the validity of the Trachyleberidae as defined by S-Bradley (1948, p. 793). The present writer feels that a more adequate generic definition of Trachyleberis Brady should preclude its being placed in a new family, and in this paper Trachyleberis Brady is left in the Cytheridae.

Genus Brachycythere Alexander, 1933 Brachycythere sphenoides (Reuss) Plate 4, Figure 16

Cythere sphenoides Reuss, 1854, Denschr. K. Akad. Wissen. Wien, vol. 7, p. 141, pl. 26, fig. 2. Alexander, 1929, Texas Univ. Bull. 2907, p. 81, pl. 7, figs. 9, 14 .
Cytheropteron sphenoides (Reuss), Jones and Hinde, 1889, Suppl. Monogr. Cret. Entom. England, Ireland, Palaeontographical Soc. London, p. 33, pl. 1, figs. 18-20.

Cytheropteron sp. B., Israelsky, 1929, Arkansas Geol. Survey, Bull. 2, p. 8, pl. 1A, figs. 2a-c.

Brachycythere sphenoides (Reuss), Alexander, 1933, Jour. Paleontology, vol. 7, p. 205, pl. 25, figs. 3a-c, 14a, b; pl. 26, figs. 7a, b; pl. 27, fig. 19.

Brachycythere sphenoides (Reuss), Swain, 1952, U. S. Geol. Survey Prof. Paper 234-B, p. 80, pl. 8, figs. 42,43 .

Dimensions: Fig. 16: length $0.90 \mathrm{~mm}$; height $0.54 \mathrm{~mm}$.

Occurrence: Black Creek only, localities G, If, I, J, and K. U.S.N.M. 128924.

Remarks: The external features of this species have recently been described by Swain (1952, p. $80)$. However, specimens from outcrop sections differ slightly but consistently in having one or more fine ridges on the ventral surface. In addition, well preserved specimens have fine spines along the antero-ventral and postero-ventral margins.

\section{Brachycythere rhomboidalis (Berry) Plate 4, Figures 5, 8, 9, 10}

Cythere rhomboidalis Berry 1925, Am. Jour. Sci., 5th ser., vol. 9, p. 481, figs. 1, 2.

Alexander, 1929, Texas Univ. Bull. 2907, p. 86, pl. 7, figs. 1, 2.

Brachycythere rhomboidalis (Berry) Alexander, 1933, Jour. Paleontology, vol. 7, no. 2, p. 206.

Brachycythere jerseyensis Jennings, 1936, Bull. Am. Paleontology, vol. 23, no. 78, p. 48, pl. 6, figs. 14a-b.

Brachycythere rhomboidalis (Berry) Schmidt, 1948, Jour. Paleontology, vol. 22, p. 414, pl. 62, figs. 8-10.

Dimensions: Fig. 8: length $0.95 \mathrm{~mm}$; height $0.47 \mathrm{~mm}$; biconvexity $0.52 \mathrm{~mm}$.

Occurrence: Peedee only, localities A, B, C, D, E, and F. U.S.N.M. 128925, 128926, 128927, 128928.

Remarks: In outline and in the possession of a deep postjacent furrow at the anterior cardinal angle these specimens resemble Brachycythere sphenoides (Reuss). The present specimens show great variation in the strength of the ventro- 
lateral punctate ridge. In both male and female dimorphs the ridge may be sharply truncate posteriorly or may merge gently into the posterior third of the valve. Striations on the ventral surface vary from strong to weak, generally being more pronounced on the shorter tumid females. Schmidt (1948, p. 414) has recently described the species.

\section{Brachycythere nausiformis Swain Plate 4, Figures 3, 4}

Brachycythere nausiformis Swain, 1952, U. S. Geol. Survey Prof. Paper 234-B, p. 80, pl. 8, figs. 44-47.

The external features of this species were adequately described by Swain (1952, p. 80).

Hinge of right valve consists of a high pointed tooth and postjacent socket; attached is a finely crenulate bar, thicker anterad, extending to a weakly notched, elongate posterior tooth projecting high on the dorsal margin. Hinge of left valve consists of an anterior socket and postjacent high pointed tooth; attached is a finely crenulate bar, thicker anterad, extending to a weakly crenulate socket. Anterior tooth and crenulate bar are separated from the dorsal margin by a depressed furrow, widest anterad and merging into crenulate socket posterad. Line of concrescence and inner margin coincide. Anterior marginal pore canals, about 34 in number, finely bifurcated. Posterior marginal pore canals, 12 in number, straight and slightly coarser than anterior canals. Deep muscle pit located anterior medianthird of valve.

Dimensions: Fig. 3: length $1.02 \mathrm{~mm}$; height $0.52 \mathrm{~mm}$; convexity $0.24 \mathrm{~mm}$.

Occurrence: Black Creek only. Swain lists the occurrence in beds of Black Creek (?) and Eutaw (?) age. Localities G, H, I, J, and K. U.S.N.M. 128929, 128930.

\section{Brachycythere plena Alexander, 1934 Plate 4, Figure 7}

Brachycythere plena Alexander, 1934, Jour. Paleontology, vol. 8, p. 216-217, pl. 33, fig. 6 . Murray and Hussey, 1942, Jour. Paleontology, vol. 16 , p. 176 , pl. 27, figs. $2,5,6$, text fig. 2, figs. 3, 7 .

Kline, 1943, Mississippi Geol. Survey, Bull. 53 , p. 67-68, pl. 8, fig. 3 .

Van den Bold, 1946, Cont. Study Ostracoda, p. 108 , pl. 13 , figs. $4-5$.

Harris and Jobe, 1951, Microfauna Midway Ark., p. 71, pl. 12, fig. 6 .

Munsey, 1953, Jour. Paleontology, vol. 27, p. 11, pl. 3, figs. 17-21.

Dimensions: Fig. 7: length $1.06 \mathrm{~mm}$; height $0.53 \mathrm{~mm}$; convexity $0.30 \mathrm{~mm}$.

Occurrence: Peedee only at surface. Peedee and unnamed Paleocene units in the subsurface. Localities A and E. U.S.N.M. 128931.

Remarks: The species has been adequately described by Alexander (1934, p. 216-217). The present specimens show the strength of the ventro-lateral ridge and "crescent-shaped" sulcus to be variable within narrow limits. In addition, our specimens show a tendency toward a faintly wrinkled or reticulate midportion adjacent to the ventro-lateral ridge.

\section{Brachycythere ledaforma (Israelsky) Plate 4, Figure 6}

Cytheropteron ledaforma Israelsky, 1929, Arkansas Geol. Survey Bull. 2, p. 8, pl. 1A, figs. 5-7.

Cythere acutocaudata Alexander, 1929, Texas Univ. Bull. 2907, p. 87, pl. 7, figs. 5, 6.

Brachycythere ledaforma (Israelsky) Alexander, 1933, Jour. Paleontology, vol. 7, p. 206, pl. 25, fig. 9 ; pl. 27, fig. 20.

Brachycythere ledaforma (Israelsky) Jennings, 1936, Bull. Am. Paleontology, vol. 23, no. 78, p. 49 , pl. 6, fig. 15 .

Shell in side view, subtriangular; widest at anterior cardinal angle; dorsal margin strongly arched, straight along hinge; ventral margin straight, slightly incised at antero-ventral junction; anterior margin broadly and obliquely rounded; posterior margin, compressed, triangular, with acute postero-ventral angle. Midportion strongly inflated, alate, and sharply truncate along venter; right valve with a short ridge surmounting ala; left valve more tumid, without ridge; a well defined furrow separates the anterior fourth from the tumid midportion, terminating dorsally, posterad of a subdued eye tubercle at the anterior cardinal angle. Surface variable, smooth to finely reticulate or punctate medially; venter with about six fine ridges or striations; a short spine present at acute posterior angle. Internal features those of the genus.

Dimensions: Fig. 6: length $0.64 \mathrm{~mm}$; height $0.26 \mathrm{~mm}$. 
Occurrence: Peedee and Black Creek, localities A, B, G, H, I, J, and K. U.S.N.M. 128932.

Remarks: The present specimens are variable in surface sculpture medially. In general outline and other features they resemble $B$. ledaforma (Israelsky). The writer considers that the minor differences shown by the present specimens are not sufficient to permit differentiation from $B$. ledaforma (Israelsky).

\section{Brachycythere raleighensis Brown, n. sp. Plate 4, Figures 11-13}

Shell in side view, ovate, subtriangular; dorsal margin strongly arched, nearly straight along the hinge line; ventral margin straight; anterior margin obliquely rounded, posterior margin compressed, triangular with subacute postero-ventral angle; left valve larger than right, most pronounced medio-dorsally.

Anterior margin ventrally, with about five short spines; posterior extremity with one or two short incipient spines. Inflated midportion reticulate, coarse puncta arranged subconcentrically. Venter with about six rows of pits parallel to the margin and separated by five ridges. Anterior furrow as in B. ledaforma.

Dimensions: Holotype: length $0.62 \mathrm{~mm}$; height $0.32 \mathrm{~mm}$; biconvexity $0.33 \mathrm{~mm}$.

Occurrence: Peedee only, localities $\mathrm{A}$ and $\mathrm{F}$. U.S.N.M. 128933, 128934, 128935.

Remarks: This species bears a strong relationship to $B$. ledaforma (Israelsky) and seems to be intermediate between that species and $B$. for $a-$ minosa Alexander from the Paleocene.

\section{Genus Alatacythere Murray and Hussey, 1942} Alatacythere alata atlantica (Schmidt)

\section{Plate 4, Figures 1, 2}

Brachycythere alata atlantica Schmidt, 1948, Jour. Paleontology, vol. 22, p. 415, pl. 61, figs. 23-24.

Carapace large in side view; left valve larger and overlaps right valve along middle dorsal margin; dorsal margin weakly concave, strongest anterad; ventral margin slightly sinuous; anterior margin broadly rounded, ventral and median thirds rimmed, with double row of about nine plate-like spines; posterior margin evenly rounded, subcaudate, with about six long plate-like spines, strongest ventrally.
Exterior smooth, translucent. Strong ala and projecting spines along ventral lateral edge. Well developed plate-like spine on posterior alial slope.

Hingement, musculature, and radial pore canals typical of the genus.

Dimensions: Fig. 1: length $0.96 \mathrm{~mm}$; height $0.51 \mathrm{~mm}$.

Occurrence: Peedee only, localities A and C. U.S.N.M. 128936, 128937.

Remarks: The writer considers the genus Alatacythere Murray and Hussey to be valid for those species that exhibit the hingement of the genotype, Alatacythere ivani (Howe and Law).

\section{Genus Trachyleberis Brady, 1898 Trachyleberis bassleri (Ulrich) Plate 7, Figures 10-14}

Cythereis bassleri Ulrich, 1901, Maryland Geol. Survey, Eocene, p. 120, pl. 16, figs. 19-21.

Weller, 1907, Geol. Survey New Jersey, vol. 4, p. 843 , pl. 110 , figs. 1-3.

? Cushman, 1925, Bull. Am. Assoc. Petroleum Geologists, vol. 9, p. 302, pl. 8, figs. 3a-c.

Alexander, 1934, Jour. Paleontology, vol. 8, p. 219-220.

Jennings, 1936, Bull. Am. Paleontology, vol. 23 , no. 78 , p. 51 , pl. 7 , figs. $1 \mathrm{a}-\mathrm{b}$.

? Van den Bold, 1946, Cont. Study Ostracoda, p. 94 , pl. 6, fig. 20 .

Schmidt, 1948, Jour. Paleontology, vol. 22, p. 422, pl. 64, fig. 13.

Swain, 1948, Maryland Geol. Survey, Bull. 2, p. 197, pl. 13, fig. 7 .

Munsey, 1953, Jour. Paleontology, vol. 27, p. 8, pl. 4, figs. $6,7,12-14$.

Cythereis bassleri lata Jennings, 1936, Bull. Am. Paleontology, vol. 23, no. 78, p. 52, pl. 7, figs. 2a-b.

Cythereis claibornensis Gooch, 1939, Jour. Paleontology, vol. 13, p. 581, pl. 67, figs. 5, 6, 10. Stephenson, 1946, Jour. Paleontology, vol. 20, p. 336 , pl. 45 , fig. 4 .

Cythereis bassleri reticulolira Schmidt, 1948, Jour. Paleontology, vol. 22, p. 423, pl. 64, figs. $14,15$.

Cythereis plusculmenis Schmidt, 1948, Jour. Paleontology, vol. 22, p. 422, pl. 64, figs. 2-4.

Paracythereis potomaca Schmidt, 1948, Jour. Paleontology, vol. 22, p. 419, pl. 64, figs. 18-19. Trachyleberis ? bassleri (Ulrich), Swain, 1951, Ostracoda from wells in North Carolina, 
pt. 1, Cenozoic Ostracoda: U. S. Geol. Survey Prof. Paper 234-A, p. 34-35, pl. 5, figs. 8, 11-15.

Dimensions: Fig. 10: length $0.82 \mathrm{~mm}$; height $0.41 \mathrm{~mm}$.

Occurrence: Peedee only, localities A and F. U.S.N.M. 128938, 128939, 128940, 128941, 128942.

Remarks: Swain (1951, p. 34-35) has recently described the species, discussed its generic position, and, at the same time, placed several previously described species in synonomy.

Specimens from the Upper Cretaceous of North Carolina show little variation in surface sculpture, but are generally more coarsely reticulate than specimens from Paleocene and Eocene sediments. The antero-median ridges in the Cretaceous specimens are very weakly developed.

\section{Trachyleberis communis (Israelsky)}

Plate 3, Figures 10, 11

Cythereis communis Israelsky, 1929, Arkansas Geol. Survey Bull. 2, p. 14, pl. 3a, figs. 9-13.

Alexander, 1929, Texas Univ. Bull. 2907, p. 101, pl. 9, fig. 18 .

Jennings, 1936, Bull. Am. Paleontology, vol. 23, no. 78 , p. 52 , pl. 7 , fig. 3.

Schmidt, 1948, Jour. Paleontology, vol. 22, p. 419 , pl. 61 , figs. 11-13.

Cythereis (Pterygocythereis) cf. C. (P) communis (Israelsky) Swain, 1948, Maryland Dept. Geol., Mines, and Water Res., Bull. 2, p. 207, pl. 14, figs. 5-7.

Carapace subquadrate in side view; greatest height at anterior cardinal angle; dorsal margin nearly straight with slight convexity in middle third; ventral margin straight, moderately converging towards dorsal margin posteriorly; anterior margin broadly rounded, thick and strongly rimmed, with four to six short, blunt spines on ventral portion; posterior margin angular and strongly compressed, bearing a weak rim, concave dorsally with three to four long, blunt spines on ventral portion. Left valve larger than right, greatest projection at anterior cardinal angle.

Ventral ridge, inflated and alate, extends off the anterior rim, rising at the anterior ventral angle and extending longitudinally parallel to and slightly overhanging the ventral margin, sparsely punctate on posterior fourth and abruptly truncated by compressed posterior ; dorsal ridge rises at anterior cardinal angle; irregular to bulbous ridge extends parallel to the dorsal margin, being less abruptly truncated by compressed posterior; median ridge, inflated in anterior third, rises from depressed area behind anterior rim and extends to compressed posterior. Hinge teeth and sockets smooth and noncrenulate.

Dimensions: Fig. 10: length $0.79 \mathrm{~mm}$; height $0.40 \mathrm{~mm}$; convexity $0.17 \mathrm{~mm}$.

Occurrence: This species is common at all Peedee localities and in most subsurface sections. Localities A, B, C, D, E, and F. U.S.N.M. 128943, 128944.

Remarks: In many of the specimens at hand there is a short ridge of variable development connecting the median and dorsal ridges at their posterior ends. Both adult forms and molts show this variable ridge development. Schmidt (1948, p. 420) mentions this feature in connection with Mt. Laurel specimens.

\section{Trachyleberis pidgeoni (Berry)}

\section{Plate 7, Figures 26, 27}

Cytheridea pidgeoni Berry, 1925, Am. Jour. Sci., 5th ser., no. 9 , p. 485 , figs. 7,8 .

Cythereis pidgeoni (Berry) Schmidt, 1948, Jour. Paleontology, vol. 22, p. 421, pl. 62 , figs. 2-6.

(Not) Swain, 1951, U. S. Geol. Survey Prof. Paper 234-A, p. 36, pl. 6, fig. 1.

Dimensions: Fig. 26: male; length $0.70 \mathrm{~mm}$; height $0.29 \mathrm{~mm}$.

height $0.30 \mathrm{~mm}$.

Fig. 27: female; length $0.61 \mathrm{~mm}$;

Occurrence: Peedee only, localities A, B, C, D, E, and F. U.S.N.M. 128945, 128946.

Remarks: Schmidt (1948, p. 421) has recently described the species. Comparison of the present specimens was made with Cythereis huntensis Alexander. The two species are probably identical and examination of a larger suite of specimens than was available to the writer would probably show $C$. huntensis Alexander and T. pidgeoni (Berry) to be dimorphic synonyms.

\section{Trachyleberis gapensis (Alexander)}

Plate 7, Figures 15-19

Cythere gapensis Alexander, 1929, Texas Univ. Bull. 2907, p. 84, pl. 6, figs. 16, 17.

The external features of this species have been adequately described by Alexander. Hinge of right 
valve consists of a high pointed tooth and subjacent socket connected to a finely crenulate interterminal groove, formed along the thickened dorsal margin, connecting posteriorly to an elongate carved tooth which lies above the groove. Hinge of the left valve the antithesis of the right. Inner margin and line of ccncrescence coincident. Anterior margin with about ten widely spaced simple pore canals; posterior margin bears about six. Hinge teeth and sockets noncrenulate. Musculature that of the genus.

Dimensions: Fig. 15 : female; length $0.54 \mathrm{~mm}$; height $0.32 \mathrm{~mm}$; biconvexity $0.28 \mathrm{~mm}$.

Fig. 16: male; length $0.63 \mathrm{~mm}$; height $0.29 \mathrm{~mm}$; biconvexity $0.27 \mathrm{~mm}$.

Occurrence: Black Creek throughout and lowermost Peedee only, localities A, C, G, H, I, and J. U.S.N.M. 128947, 128948, 128949, 128950, 128951.

Remarks: The present specimens are slightly more acute posteriorly and the ventral and median ridges terminate approximately along the same vertical line, otherwise they are conspecific with C. gapensis Alexander. Sexual dimorphism is marked with male dimorphs being nearly onethird longer than the females.

Trachyleberis (?) praecursora Brown, n. sp. Plate 7, Figures 20-25

Carapace small, subrhomboidal in lateral view ; dorsal margin straight; ventral margin straight to concave medially; anterior margin broadly and evenly rounded; posterior margin angulate, pointed.

Anterior margin strongly and finely denticulate with about 20 spines, more pronounced ventrally; posterior margin with about four blunt spines ventrally; a short ridge, highest posterad, rises near the antero-ventral junction, extends adjacent to and above the ventral margin, swings gently inward medially, and terminates above abruptly compressed posterior; a faint dorsal ridge, highest posteriorly, commences postjacent to a subdued eye tubercle, outlines the dorsal margin above, turns inward posterad, and terminates above compressed anterior; a median ridge commences in the anterior third, ventrally, passes through the inflated subcentral node and connects to the dorsal ridge posteriorly. Surface, medially, is discretely reticulate, anterior and posterior thirds smooth.

Hinge in right valve a high ovate pointed tooth and large ovate postjacent socket, long interterminal bar terminating in a weak elongate socket connected to a high rounded tooth formed at outward inflation of marginal area; left valve antithesis of right. Inner margin and line of concrescence coincide, not perfectly coincident along anterior; deep subcentral depression. Musculature that of the genus.

Dimensions : Holotype: length $0.53 \mathrm{~mm}$; height $0.28 \mathrm{~mm}$; biconvexity $0.20 \mathrm{~mm}$.

Occurrence: Lower Peedee only. This species apparently occurs only in the Exogyra cancellata subzone, localities A and F. U.S.N.M. 128952, 128953, 128954, 128955, 128956, 128957.

Remarks: Female dimorphs can be distinguished by their relatively shorter and broader carapaces. The species is provisionally placed in Trachyleberis Brady because of slight differences in hingement from that given for Trachyleberis Brady. Our specimens show a slight swelling (secondary tooth?) at the anterior end of the interterminal bar in the left valve and a corresponding shallow socket in the right valve. Comparison with Toulmina Munsey (Munsey, 1953. p. 6) may show our species to belong to that genus.

\section{Genus Platycythereis Triebel, 1940} Platycythereis costatana angula (Schmidt) Plate 6, Figures 22-25

Cythereis costatana angula Schmidt, 1948, Jour. Paleontology, vol. 22, p. 420 , pl. 61 , figs. $17-$ 18.

Paracythereis semilenis Schmidt, 1948, Jour. Paleontology, vol. 22, p. 418, pl. 61, fig. 14. Carapace subquadrate in side view ; dorsal margin straight to slightly convex; ventral margin straight; anterior margin broadly and evenly rounded, strongly and broadly rimmed, spinose; posterior margin compressed, subtriangular, sharply rounded, weakly rimmed, spinose.

Rounded ridge, reticulate anterad-punctate posterad, extends from just behind anterior dorsal angle back along dorsal margin to posterior dorsal angle, turns at right angles, and extends parallel to and above dorsal third of compressed posterior. A second short ridge extends from just anterad of midlength back along ventral margin to posterior ventral angle, turns at right angles, and extends parallel to and above ventral third of compressed posterior. Posterior margin with about six well developed spines on dorsal third. 
Subdued subcentral node. Anterior third bears two rows of coarse reticulations, one row of which passes along and continues on underside of the dorsal ridge. Middle and anterior thirds punctate. Hingement and musculature that of the genus.

Dimensions: Fig. 22: length $0.72 \mathrm{~mm}$; height $0.35 \mathrm{~mm}$; biconvexity $0.16 \mathrm{~mm}$.

Occurrence: Peedee only, localities A and C. U.S.N.M. 128958, 128959, 128960, 128961.

Remarks: The flat compressed carapace, hingement, marginal rims, and very subdued subcentral node of this species place it in the genus Platycythereis Triebel. The writer has compared the more strongly spinose molts identified by Schmidt as Paracythereis semilenis Schmidt with the species at hand and considers them to be conspecific.

Genus Protocythere Triebel, 1938 Protocythere paratriplicata Swair:

Plate 3, Figures 16, 17

? Cythere foersteriana Bosquet, Alexander, 1929, Texas Univ. Bull. 2907, p. 82, pl. 6, figs. $1,11$.

(Not) Bosquet, 1847, Mem. Soc. Roy. Sci.

Liege, nol. 4, p. 364, pl. 2, figs. 4a-d.

Protocythere paratriplicata Swain, 1952, U. S. Geol. Survey Prof. Paper 234-B, p. 85, pl. 9, figs. 18-21.

Swain has recently described this species and discussed its generic position.

Dimensions: Fig. 16: length $0.61 \mathrm{~mm}$; height $0.27 \mathrm{~mm}$.

Occurrence: Black Creek only, localities G, J, and K. U.S.N.M. 128962, 128963.

Remarks: Specimens from the outcropping sections are generally smaller than the holotype described by Swain from a well section, otherwise they are judged to be conspecific. Average length of the present specimens is $\pm 0.60 \mathrm{~mm}$.

\section{Genus Progonocythere Sylvester-Bradley,}

\section{8}

Progonocythere caswellensis Brown, n. sp.

Plate 4, Figures 14, 15

Carapace small, subquadrate in lateral view; widest anterad, highest just posterad of median; dorsal margin straight; ventral margin slightly concave medially ; anterior margin broadly xounded, finely spinose ventrally; posterior margin less broadly rcunded, slightly extended medially, finely spinose.

Entire valve surface covered with high, narrow square-sided ridges, vertically aligned and more pronounced ventrally; ridges on the anterior third are slightly longer and roughly subparallel to the anterior margin; dorsad and posterad, the ridges are more subdued. Closely spaced squaresided ridges and deep interridge areas give the valves a very distinct deeply reticulate appearance, vertically aligned.

Hinge of left valve with terminal elongate denticulate sockets and a finely crenulate interterminal bar all located high on the marginal rim. Hinge of right valve counterpart of the left.

Dimensions : Holotype : length $0.63 \mathrm{~mm}$; height $0.31 \mathrm{~mm}$; convexity $0.16 \mathrm{~mm}$.

Occurrence: Peedee only, localities A, C, and F. U.S.N.M. $128964,128965$.

Remarks: This species bears closest resemblance to Progonocythere hieroglyphica Swain and Peterson from the Sundance formation of Jurassic age. This is the first recorded occurrence of the genus in the Cretaceous.

\section{Genus Cytheridea Bosquet, 1850}

Stephenson (1936) erected several subgenera under the genus Cytheridea Bosquet. Among these subgenera were Haplocytheridea and Clithrocytheridea which Stephenson, at a later date (1946), raised to the rank of genera. The critical point of distinction between Haplocytheridea and Clithrocytheridea was defined as slight differences in hingement. Cretaceous specimens of Haplocytheridea and Clithrocytheridea from North Carolina exhibit hinge structure in which hingement as defined for both Haplocytheridea and Clithrocytheridea is present in the same species. In addition, reversal of hingement, in which the normal (?) dentition of a right valve appears in the left valve, is commonly observed. Schmidt (1948) commented on this mixed dentition in connection with Cretaceous specimens. Swain (1952) and Alexander (1933) have pointed out cases of reversal of hingement and valve overlap in Cretaceous Cytheridea.

In this paper both Haplocytheridea and Clithrocytheridea are reduced in rank to subgenera with the feeling that further revision will be necessary as additional populations are studied. Species in this paper are given as Cytheridea (Haplocytheridea) if they exhibit a prominent accom- 
modation groove dorsad of the interterminal area, whereas species are given as Cytheridea (Clithrocytheridea) if the accommodation groove and attendant valve overlap relationships are absent.

Subgenus Haplocytheridea Stephenson, 1936 Cytheridea (Haplocytheridea) fabaformis (Berry)

Plate 2, Figures 7, 8

Cytherella fabaformis Berry, 1925, Am. Jour. Sci., 5th ser., vol. 9, p. 487, fig. 13.

Cytheridea fabaformis Alexander, 1929, Texas Univ. Bull. 2907, p. 76, pl. 5, fig. 18.

Alexander, 1934, Jour. Paleontology, vol. 8, p. 224.

Haplocytheridea ? fabaformis ( B e r r y), Schmidt, 1948, Jour. Paleontology, vol. 22, p. 426 , pl. 62 , fig. 23 , text fig. 2 e.

Haplocytheridea ? fabaformis var. multilira

Schmidt, 1948, Jour. Paleontology, vol. 22, p. 426 , pl. 62 , figs. $25,26$.

Dimensions: Fig. 7 : female; length $0.60 \mathrm{~mm}$; height $0.34 \mathrm{~mm}$.

height $0.30 \mathrm{~mm}$.

Fig. 8: male; length $0.64 \mathrm{~mm}$;

Occurrence: Peedee only, localities A, B, C, D, E, and F. U.S.N.M. 128966, 128967.

Remarks: North Carolina specimens are identical with those specimens occurring in the Monmouth formation and originally described by Berry, 1925. A variety $H$. ? fabaformis multilira Schmidt was described by Schmidt, 1948. Examination has shown the species and variety to reflect only minor differences and the two are considered to be conspecific by the writer.

\section{Cytheridea (Haplocytheridea) sarectaensis \\ Brown, n. sp. \\ Plate 7, Figures 1-3}

Shell in side view, oblong-ovate; highest medi. ally; dorsal margin convex; ventral margin straight; anterior broadly rounded with about ten short spines, most pronounced ventrally; posterior margin obliquely rounded, slightly extended ventrally, with about seven short spines along posteroventral margin.

Surface of valves strongly pitted, puncta arranged in about nine subvertical rows separated by short rounded ridges, in the anterior and median two-thirds of valve; furrows most pronounced medio-dorsally, incipient furrows extend to a rounded steep posterior slope; anterior fourth rounded, slopes steeply to wide slanting anterior margin. Anterior and posterior thirds, ventrally, with a slight bulbous protrudance. Internal features those of the genus.

Dimensions: Holotype : length $0.75 \mathrm{~mm}$; height $0.40 \mathrm{~mm}$; biconvexity $0.38 \mathrm{~mm}$.

Occurrence: Peedee only, locality E. U.S.N.M. 128968, 128969, 128970.

Remarks: This species belongs to the large group which includes Cytheridea (H.) moodyi, Cytheridea (H.) veatchi, Cytheridea (H.) veatchi aquia, and Cytheridea (H.) ruginosa. The present specimens are closest to $C$. ruginosa Alexander in ornamentation. They are higher anteriorly and posteriorly with steeper posterior and anterior slopes than that species, and more tumid in lateral view. Female dimorphs are shorter and more tumid than the males.

\section{Cytheridea (Haplocytheridea) councilli Brown, n. sp. \\ Plate 2, Figures 12-16}

Carapace in side view, elongate-ovate; highest post-median, widest behind anterior cardinal angle; dorsal margin convex; ventral margin straight to slightly sinuous; anterior margin rounded, obtuse dorsally; ventral margin less evenly rounded, weakly acuminate ventrally. Left valve larger than right except along anterior margin, overlap greatest along postero-ventral third.

Entire carapace very coarsely and evenly pitted, deepest pits (about six) are behind and parallel to the anterior margin. Viewed ventrally the anterior margin on both valves is weakly rimmed below.

Hinge of right valve consists of terminal notched cusps connected by a narrow crenulate bar postjacent to the dorsal margin. The left valve bears narrow notched sockets connected by a narrow crenulate groove, separated from dorsal margin by a very weakly grooved shelf. Musculature that of the genus.

Dimensions : Holotype : length $0.59 \mathrm{~mm}$; height $0.26 \mathrm{~mm}$; biconvexity $0.21 \mathrm{~mm}$.

Occurrence: Peedee only, localities A, B, D, and F. U.S.N.M. 128971, 128972, 128973, 128974, 128975 .

Remarks: The coarsely pitted surface and rimmed anterior margin serves to distinguish this species. Named for Richard Councill, geologist, Atlantic Coast Line Railroad. 


\section{Cytheridea (Haplocytheridea) plummeri Alexander}

Plate 2, Figures 9-11

Cytheridea plummeri Alexander, 1929, Texas Univ. Bull. 2907, p. 73, pl. 5, figs. 5-8.

Alexander and Alexander, 1933, Am. Midland Naturalist, vol. 14, no. 3, p. 283, figs. 1-4.

Haplocytheridea ? plummeri (Alexander) Schmidt, 1948, Jour. Paleontology, vol. 22, p. 425 , pl. 62 , figs. $27-29$; text fig. 2 f.

Haplocytheridea ? sp. aff. H. ? plummeri (Alexander) Swain, 1952, U. S. Geol. Survey Prof. Paper 234-B, p. 79, pl. 8, fig. 15.

These specimens agree with Alexander's description. The species as illustrated by Alexander shows anterior and postero-ventral spines. The present specimens have about 12 sharp welldefined spines along the anterior margin medially and ventrally. About six sharp spines, angled posteriorly, extend along the posterior third of the ventral margin to the posterior acumination of the right valve. Spines weak to absent on the left valve.

Left valve hinge consists of anterior and posterior sockets connected by a crenulate groove and separated from the dorsal margin by a well developed accommodation groove (Ausweichfurche). Right valve consists of terminal notched teeth separated by a narrow crenulate bar and lying above a shallow groove adjacent to the dorsal margin. Musculature that of the genus.

Dimensions: Fig. 9: male; length $0.80 \mathrm{~mm}$; height $0.39 \mathrm{~mm}$.

Fig. 10 : female; length $0.69 \mathrm{~mm}$;

height $0.40 \mathrm{~mm}$.

Occurrence: Peedee only, localities A and D. U.S.N.M. 128976, 128977, 128978.

\section{Cytheridea (Haplocytheridea) wilmingtonensis Brown, n. sp. \\ Plate 7, Figures 4-9}

Carapace in side view, ovate; left valve markedly larger than right around entire periphery; dorsal margin strongly convex; ventral margin sinuous; anterior margin broadly rounded; posterior margin less strongly rounded, extended ventrally; anterior margin weakly denticulate below; posterior margin with two to three weak spines at postero-ventral junction.
Surface of right valve: punctate, arranged in vertical rows or weak furrows, medially; posterior fourth bears a short, bulbous sub-ventral ridge, flanked anterad and posterad by short concave furrows; post-medially is an irregular bulbous ridge, anterad of which is a depressed area adjacent to the dorsal margin and containing one or two irregularly oblique furrows which die out medially. Surface of left valve: the anterior half of this valve is the antithesis of the right valve, the posterior third is smoothly convex lacking the ridge and furrows of its right valve counterpart.

Muscle scar consists of four round spots in a sub-vertical row located slightly antero-median, forward of which are two more spots. Inner margin and line of concrescence coincide. Hingement and musculature that of the genus.

Dimensions: Holotype: length $0.57 \mathrm{~mm}$; height $0.33 \mathrm{~mm}$; biconvexity $0.25 \mathrm{~mm}$.

Occurrence: Peedee only, locality A. U.S.N.M. 128979, 128980, 128981, 128982, 128983, 128984.

Remarks: In outline, arrangement of surface ridges and furrows, and in internal features the present specimens are judged to belong to the subgenus Haplocytheridea Stephenson. The degree of overlap and strength of surface sculpture is very variable with the locality but not within the locality. The same variability is present in specimens from various wells. The species is apparently confined to the basal Peedee and should make an excellent marker for picking the PeedeeBlack Creek contact.

\section{Cytheridea (Haplocytheridea) ulrichi (Berry) Plate 2, Figures 4, 5}

Cythere ulrichi Berry, 1925, Am. Jour. Sci., 5th ser., vol. 23 , no. 9 , p. 483 , fig. 3.

Haplocytheridea ? ulrichi (Berry), Schmidt, 1948, Jour. Paleontology, vol. 22, p. 426, pl. 62, figs. 18, 19.

Dimensions: Figure 4: male; length $0.61 \mathrm{~mm}$; height $0.33 \mathrm{~mm}$; biconvexity $0.27 \mathrm{~mm}$.

Occurrence: Peedee only, localities A, B, C, D, E, and F. U.S.N.M. 128985, 128986.

Remarks: Internal and external features of this species have been adequately described by Schmidt, 1948. The hinge structure as described by Schmidt is present in the North Carolina specimens. The writer considers this hinge structure 
to represent a variant of that commonly found in the subgenus Haplocytheridea Stephenson. These atypical examples of hinge structure are in need of further study as has been pointed out by the writer and others. Schmidt (1948, p. 426) has recently described the species.

\section{Cytheridea (Haplocytheridea) carolinensis Brown, n. sp. \\ Plate 2, Figures 17-20}

Shell subtriangular in side view; highest medially; dorsal margin gently convex, straight posterad; ventral margin sinuous; anterior margin broadly and evenly rounded; posterior margin less broadly rounded. Left valve larger than right except along anterior margin.

Posterior and anterior fourths inflated, surmounted by bulbous ridges subparallel to anterior and posterior margins respectively; anterior slope in front and below ridge sharply truncate, passing into compressed marginal area; posterior slope sharply truncate dorsally, bulbous above ventrally, passing into narrowly compressed marginal area.

Surface finely reticulate in posterior and anterior thirds; medially, between bulbous extremities, are three to four deeply pitted furrows more pronounced anterad and dorsad.

Hinge of left valve; terminal crenulate sockets and narrow crenulate interterminal groove, separated from dorsal margin by weakly developed accommodation groove. Hinge of right valve antithesis of left.

Dimensions: Holotype : length $0.56 \mathrm{~mm}$; height $0.30 \mathrm{~mm}$; biconvexity $0.22 \mathrm{~mm}$.

Occurrence: Peedee only, localities A, D, and F. U.S.N.M. 128987, 128988, 128989, 128990.

Remarks: In bulbous extremities this species resembles $C$. oblongus n. sp. (p. 19). The medial pitted furrows and bulbous ends serve to distinguish this species. Female dimorphs are shorter and more tumid, medially, than the males.

\section{Cytheridea (Haplocytheridea) punctura} (Schmidt)

Plate 2, Figures 26-28

Haplocytheridea punctura Schmidt, 1948, Jour. Paleontology, vol. 22, p. 425 , pl. 61, figs. 27 31.

Dimensions: Fig. 26 : female; length $0.70 \mathrm{~mm}$; height $0.46 \mathrm{~mm}$. height $0.44 \mathrm{~mm}$.

Fig. 27: male; length $0.82 \mathrm{~mm}$;

Occurrence: Peedee only, localities A, C, E, and F. U.S.N.M. 128991, 128992, 128993.

Remarks: Schmidt (1948, p. 425) has recently described the species.

Cytheridea (Haplocytheridea) monmouthensis Berry

Plate 2, Figure 6

Cytheridea monmouthensis Berry, 1925, Am. Jcur. Sci., 5th ser., vol. 9, p. 486, fig. 10.

Alexander, 1929, Texas Univ. Bull. 2907, p. 74 , pl. 5, figs. 11-14.

Cytheridea (Haplocytheridea) monmouthensis Berry, Swain, 1948, Maryland Dept. Geology, Mines, and Water Res. Bull. 2, p. 212, pl. 14, fig. 14.

Haplocytheridea monmouthensis ( B e r ry) Swain, 1952, Ostracoda from Wells in North Carolina: pt. 2, Mesozoic Ostracoda, U. S. Geol. Survey Prof. Paper 234-B, p. 79, pl. 8, fig. 19 .

Dimensions: Fig. 6 : female; length $0.68 \mathrm{~mm}$; height $0.44 \mathrm{~mm}$; biconvexity $0.33 \mathrm{~mm}$.

Occurrence: Peedee and Black Creek, localities A, C, D, G, H, I, J, and K. U.S.N.M. 128994.

Remarks: The strength of the median subvertical furrows varies with individuals. Internal features that of the genus. Swain (1952, p. 79) has recently described the species.

Subgenus Clithrocytheridea Stephenson, 1936 Cytheridea (Clithrocytheridea) oblongus

Brown, n. sp.

Plate 2, Figures 21-25

Carapace in side view, oblong; highest anteromedian, widest medially; dorsal margin slightly arched along anterior third, straight along posterior third; ventral margin sinuous, concave medially; anterior margin rounded, obtuse ventrally ; posterior margin more sharply rounded, obtuse ventrally. Left valve larger than right and overlaps, most pronounced ventrally and along postero-dorsal third.

Carapace finely reticulate, irregular; reticulations extend laterally in closely-spaced irregular rows along median and ventro-lateral surfaces; reticulations are subarcuate along dorsal portions of carapace. There is an inflated ridge paralleling the anterior margin which is sharply truncate in front; a posterior ridge above the posterior margin is sharply truncate at the posterior margin 
ventrally with a somewhat gentler slope dorsally. In ventral view the anterior and posterior margins appear square above and below, gently sloping to the margin medially.

Right valve consists of terminal notched cusps, separated by a finely denticulate groove along the dorsal margin. Left valve consists of terminally notched sockets and a finely crenulate bar below the dorsal margin. Line of concrescence and inner margin coincide except along anterior margin where they are widely separated ventrally. Musculature that of the genus.

Dimensions : Holotype : length $0.60 \mathrm{~mm}$; height $0.25 \mathrm{~mm}$; biconvexity $0.22 \mathrm{~mm}$.

Occurrence: Lower Peedee only, localities A and F. U.S.N.M. 128995, 128996, 128997, 128998, 128999.

Remarks: This small distinct species occurs only rarely in the subsurface. Female dimorphs are shorter and slightly more tumid than the males.

Genus Cytheropteron Sars, 1865 Subgenus Cytheropteron Sars, s. s. Cytheropteron (Cytheropteron) penderensis Brown, n. sp.

Plate 6, Figures 12, 13

Carapace subovate in lateral view; highest posterad of midlength; dorsal margin moderately arched; ventral margin straight, slightly sinuous anterad; anterior margin evenly rounded; posterior margin sharply rounded, extended in a blunt, compressed caudal process. Left valve slightly larger than right.

Ventral third of valve strongly inflated, topped by a weak sinuous ridge; inflated portion of valve covers marginal area ; postero-ventral slope sharply truncate. Medially, valves are coursely reticulate with separating sinuous ridges generally aligned normal to the alate ridge. Hingement and muscle scar that of the genus.

Dimensions : Holotype: length $0.55 \mathrm{~mm}$; height $0.32 \mathrm{~mm}$; convexity $0.21 \mathrm{~mm}$.

Occurrence: Peedee only, localities A and C. U.S.N.M. 129000, 129001.

Subgenus Eocytheropteron Alexander, 1933 Cytheropteron (Eocytheropteron) straillis Brown, n. sp.

Plate 6, Figures 14, 15

Shell acuminate-ovate in lateral view; highest medially; dorsal margin moderately convex; ventral margin straight; anterior margin broadly and evenly rounded; posterior margin narrowly rounded with a blunt compressed caudate extension ventro-medially. Ventral half of valves swollen, sharply truncate, overhanging or concealing marginal area medially. Anterior third of valves bear three to four subdued ridges parallel to anterior margin. Median third coarsely punctate with about 20 coarse, widely-spaced pits.

Hinge in left valve bears an anterior shallow crenulate socket, a long weakly crenulate bar connecting to a crenulate posterior socket which lies below the marginal area; a very subdued groove separates the interterminal bar from the dorsal margin. Muscle scar that of the genus.

Dimensions : Holotype : length $0.69 \mathrm{~mm}$; height $0.36 \mathrm{~mm}$.

Occurrence: Peedee only, localities A, D, and F. U.S.N.M. 129002, 129003.

\section{Cytheropteron (Eocytheropteron) striatum Brown, n. sp. \\ Plate 6, Figures 16, 17}

Carapace small, egg-shaped; highest and widest medially; dorsal margin gently arched, straight along the hinge line; ventral margin more strongly arched, weakly angulate medially; anterior margin rounded, slightly extended medially; posterior margin subtriangular, bluntly caudate medially. Venter is inflated and overhangs margin medially.

Midportion of valves moderately punctate. Posterior third, ventrally, with about four fine widelyspaced ridges on each valve; ridges swing down and forward along the ventral surface, swing up and across the anterior third terminating anterad of the anterior cardinal angle.

Internal features those of the genus.

Dimensions : Holotype: length $0.51 \mathrm{~mm}$; height $0.26 \mathrm{~mm}$; biconvexity $0.22 \mathrm{~mm}$.

Occurrence: Black Creek only, localities G, H, I, J, and K. U.S.N.M. 129004, 129005.

Genus Velarocythere Brown, n. gen. Type species: Velarocythere scuffeltonensis Brown, n. sp.

Shell oblong-ovate in lateral view, may be gross- 
ly inflated; greatest height median; dorsal margin gently convex to sinuous; ventral margin straight with a concave reentrant antero-medially; anterior margin broadly and evenly rounded, spinose below, with one or two rows of deep oblong pits behind and immediately adjacent to the margin; posterior margin less broadly rounded to subacute. Coarsely unisulcate or bisulcate subjacent to the anterior cardinal angle. Left valve typically larger than right, most conspicuous overlap along dorsum and anterad of anterior cardinal angle. Cardinal angles obtuse. Convexity of valves strong; surface of valves grossly reticulate to smooth and sparsely punctate.

Hinge of right valve consists of a high pointed anterior tooth, notched anterad, a subjacent ovate socket connecting with a wide faintly crenulate groove lying along the dorsal margin and terminating posterad at a large square-tooth at the posterior cardinal angle. Left valve antithesis of the right. Line of concrescence and broad inner margin coincident. Muscle scar, located in a shallow submedian pit, consists of a curvilinear row of three spots and a single larger anterior spot. Female dimorphs are shorter and more tumid than the male.

Geologic range: Upper Cretaceous

Relationships: This genus shows some affinity to Anticythereis Van den Bold (Pseudocythereis Jennings) but can be separated on the basis of size, hingement, and external shell characteristics.

\section{Velarocythere scuffeltonensis Brown, n. sp. Plate 5, Figures 5-9}

Carapace oblong-ovate in lateral view; widest anterad; highest medially; dorsal margin weakly convex, sinuous posterad; ventral margin slightly concave antero-medially; anterior margin broadly rounded; posterior margin more narrowly rounded; left valve larger than right, extending beyond the right along the ventrum and markedly at the broadly obtuse cardinal angles.

Midportion of valves strongly inflated; ends slightly compressed; entire valve surface very coarsely reticulate; outlining the anterior margin posterad are two concentrically arranged rows of deep depressions bounded dorsally by a short oblique sulcus adjacent to the anterior cardinal angle and extending to the dorsal margin just posterad of the anterior cardinal angle.

Hinge of right valve consists of a high rounded anterior tooth and postjacent socket, a long wide crenulate interterminal bar connecting to a high square posterior tooth; left valve antithesis of right. Line of concrescence and broad inner margin coincident. Muscle scars, located in a shallow submedian pit, consist of a subvertical row of three spots and a single anterior spot.

Dimensions: Holotype: female; length 0.75 $\mathrm{mm}$; height $0.34 \mathrm{~mm}$; biconvexity $0.35 \mathrm{~mm}$.

Occurrence: Peedee only, localities A, C, and F. U.S.N.M. 129006, 129007, 129008, 129009, 129010.

\section{Velarocythere legrandi Brown, n. sp. Plate 5, Figures 1-4}

Carapace subovate in side view; widest in anterior third; greatest height medially; dorsal margin gently convex to sinuous; ventral margin slightly concave medially; anterior margin broadly rounded, compressed; posterior margin less broadly rounded, compressed; ends bear two parallel rows of five spines; left valve larger than right, extending beyond the other ventrally and at the broadly obtuse cardinal angles.

Midportion of valves very strongly inflated with a tumid overhang ventrally, sharply truncate anterad and separated from the anterior fourth by a sharp elliptical ridge which terminates at the dorsal margin medially, and lies above and subparallel to the ventral margin, terminating subjacent to the postero-ventral junction; midportion of valve grossly and subconcentrically reticulate; compressed posterior one-fourth smooth to slightly papillose ventrally; the anterior fourth, below the sharp elliptical ridge, bears two concentric rows of deep depressions bounded dorsally by a shallow oblique sulcus subjacent to the anterior cardinal angle.

Dimensions : Figs. 3, 4 : length $0.82 \mathrm{~mm}$; height $0.33 \mathrm{~mm}$; biconvexity $0.39 \mathrm{~mm}$.

Occurrence: Peedee only, localities $\mathrm{A}$ and $\mathrm{C}$. U.S.N.M. 129011, 129012.

Remarks: The grossly reticulate midportion readily distinguishes this species. Named for $H$. E. LeGrand, U. S. Geological Survey.

\section{Velarocythere cacumenata Brown, n. sp. Plate 5, Figures 13-15}

Shell in side view, oblong-ovate; widest at anterior one third; highest post-medially; dorsal margin weakly convex, sinuous posterad; ventral margin slightly concave medially; ends rounded, finely spinose. Left valve larger than right, extending beyond the right along the ventrum and markedly at the broad and obtuse cardinal angles. Dorsal edge thickened. 
Surface of valves glossy, evenly and discretely pitted. Midportion of valves strongly inflated with bulbous and overhanging expansions along the dorsum and ventrum post-medially; bulbous portions lie on either side of a broad, shallow postmedian sulcus; outlining the anterior margin, posterad, is a row of about five deep coarse depressions, most pronounced medially and truncated dorsad by a short oblique sulcus adjacent to the anterior cardinal angle. Hingement and musculature that of the genus.

Dimensions : Holotype: length $0.72 \mathrm{~mm}$; height $0.35 \mathrm{~mm}$; biconvexity $0.36 \mathrm{~mm}$.

Occurrence: Peedee only, localities A, C, and F. U.S.N.M. 129013, 129014, 129015.

Remarks: The deep anterior pits characteristic of the genus are not as well developed as in other species of Velarocythere.

Velarocythere eikonata Brown, n. sp. Plate 5, Figures 10-12

The shape, overlap, and valve sculpture of this species is identical with that described for $V$. cacumenata with one exception. The surface of this species is coarsely reticulate, with large, broad deep pits, and not glossy and discretely pitted as in $V$. cacumenata.

Dimensions : Holotype : length $0.68 \mathrm{~mm}$; height $0.33 \mathrm{~mm}$; biconvexity $0.33 \mathrm{~mm}$.

Occurrence: Peedee only, localities A, C, and F. U.S.N.M. 129016, 129017, 129018.

Remarks: The smooth shelled $V$. cacumenata occurs higher stratigraphically in the Peedee formation than $V$. eikonata.

\section{Velarocythere arachoides (Berry) \\ Plate 5, Figures 16-18}

Cythere arachoides Berry, 1925, Am. Jour. Sci., 5 th ser., vol. 9 , p. 484, fig. 5 .

Cythere rectangulapora Berry, 1925, Am. Jour. Sci., 5th ser., vol. 9, p. 483 , fig. 4.

Brachycythere arachoides (Berry), Schmidt, 1948, Jour. Paleontology, vol. 22, p. 415, pl. 62, figs. 13-16.

Brachycythere arachoides (Berry), Swain,
1952, U. S. Geol. Survey Prof. Paper 234-B, p. 81 , pl. 9 , fig. 22 .

Shell in side view, subpyriform; highest postmedian; dorsal margin weakly arched, sinuate anterad; ventral margin straight, convex medially; anterior margin evenly rounded; posterior margin sharply rounded, extended medially. Valves subequal, left valve larger than right, overlap greatest at cardinal angles.

Anterior margin compressed, smooth dorsally, coarsely pitted ventrally with two rows of subparallel deep pits; posterior margin smooth, compressed; centrally, valves strongly inflated, coarsely reticulate; strong submedian pit behind and below anterior cardinal angle, bounded dorsally by a short deep furrow forming a reentrant in dorsal margin; ventrally pit is bounded by subcentral short ridge and subjacent furrow.

The right valve hinge consists of a high pointed tooth with postjacent socket slightly below a long smooth bar, medially formed by the thickened valve edge, a high posterior square-shaped blunt tooth slightly below the interterminal bar. The left valve hinge consists of a deep socket with postjacent high pointed tooth, a long bar formed by the thickened valve edge and connected to an elongate square-shaped socket. Musculature, located in pit situated dorso-medially below anterior end of interterminal bar, consists of an L-shaped scar on the anterior pit slope and three elongate scars on the posterior pit slope.

Dimensions: Fig. 16: length $0.75 \mathrm{~mm}$; height $0.34 \mathrm{~mm}$.

Occurrence: Peedee only, localities A, B, C, E, and F. U.S.N.M. 129019, 129020, 129021.

Remarks: The hingement, musculature and shape of the carapace exhibited by this species differs in detail from that described for Brachycythere Alexander. The valve overlap, obtuse cardinal angles, deep subparallel pits behind the anterior margin and general surface sculpture place these specimens in the new genus Velarocythere Brown. Compare dentition of Brachycythere Alexander (Plate 4, Fig. 10) with that of Velarocythere Brown (Plate 5, Fig. 18). Note the shape and position of the posterior tooth in both figures. 
Genus Cytherideis Jones, 1856

Cytherideis mayeri (Howe and Garrett).

Plate 3, Figures 12, 13

Bythocypris ? mayeri Howe and Garrett, 1934, Louisana Dept. Cons., Geol. Bull. no. 4, p. 29, pl. 1, figs. 8-10.

Xestoleberis mayeri (Howe and Garrett), Schmidt, 1948, Jour. Paleontology, vol. 22, p. 410 , pl. 63 , fig. 10, fig. 2 (text).

Cytherideis mayeri (Howe and Garrett), Blake, 1950, Jour. Paleontology, vol. 24, p. 179.

Munsey, 1953, Jour. Paleontology, vol. 27, p. 13, pl. 3 , fig. 4 .

Dimensions: Fig. 13: length $0.73 \mathrm{~mm}$; height $0.29 \mathrm{~mm}$; convexity $0.16 \mathrm{~mm}$.

Occurrence: Peedee only. This species is rare to common in subsurface Eocene and Paleocene formations in North Carolina. Localities A and $\mathrm{E}$. U.S.N.M. 129022, 129023.

Remarks: Schmidt (1948, p. 410) has recently described the species.

Genus Monoceratina Roth, 1928 Monoceratina biloba Schmidt Plate 3, Figures 14, 15

Monoceratina biloba Schmidt, 1948, Jour. Paleontology, vol. 22 , p. 412 , pl. 61 , fig. 9 .

Dimensions: Fig. 14: length $0.45 \mathrm{~mm}$; height $0.27 \mathrm{~mm}$.

Occurrence: Peedee, locality A. U.S.N.M. 1290 24, 129025.

Remarks: Only one specimen, a molt, was obtained at the outcrop during the present study. The bulbous node on the ventral lobate area is well developed on our specimen, a right valve. Also figured is a complete carapace from a water well at the Oak Grove Air Base, Jones County, N. C. This specimen was taken from a sample at 200-210 feet, Peedee formation. Schmidt (1948, p. 412) has recently described the species.

Genus Loxoconcha Sars, 1866 Loxoconcha neusensis Brown, n. sp. Plate 6, Figure 10

Carapace long in relation to width, subquadrate in lateral view; dorsal margin straight; ventral margin sinuous; anterior margin broadly rounded; posterior margin rounded ventrally, slightly angulate to straight dorsally, bluntly caudate. Anterior and posterior ends compressed, posterior more so. Surface coarsely reticulate with rounded to angular pits generally subcircular in relation to margins. Ribs most prominent posteroventrally.

Dimensions: Holotype : length $0.55 \mathrm{~mm}$; height $0.19 \mathrm{~mm}$; biconvexity $0.18 \mathrm{~mm}$.

Occurrence: Peedee only, localities A, C, and E. U.S.N.M. 129026.

Remarks: This species is close to $L$. fletcheri Israelsky from the Cretaceous of Texas and Arkansas. It is more tumid and the posterior margin less rounded than that species.

\section{Loxoconcha seraphae Brown, n. sp. Plate 6, Figures 9-11}

Carapace subelliptical in lateral view; highest medially; widest just posterad of median; dorsal margin straight; ventral margin gently convex, swinging upward to a blunt submedial caudate process; anterior margin broadly rounded, faintly rimmed above and below; posterior obtusely angled dorsally; postero-ventral margin bears a strong lateral keel.

Surface strongly reticulate, punctate; puncta arranged in subcircular rows generally converging posterad and anterad.

Hinge characteristic of genus. Inner margin and line of concrescence distinctly separate along anterior margin.

Dimensions: Holotype: length $0.52 \mathrm{~mm}$; height $0.32 \mathrm{~mm}$; biconvexity $0.20 \mathrm{~mm}$.

Occurrence: Peedee only, localities A, C, E, and F. U.S.N.M. 129027, 129028.

Genus Orthonotacythere Alexander, 1933

Orthonotacythere sulcata Brown, n. sp. Plate 6, Figures 6-8

Shell small, quadrate in side view; dorsal margin straight; ventral margin convex; anterior margin broadly and evenly rounded; posterior margin obtusely rounded, moderately caudate dorsally.

Antero-median broad vertical sulcus separates anterior third from posterior two-thirds of valve. Surface finely and evenly reticulate. Eight prominent tubercles on the valves; two anterior tubercles lie behind and adjacent to the anterior margin; three tubercles, most pronounced posterad, parallel and lie above the ventral margin; 2 weak tubercles subparallel and above the posterior margin medially and dorsally; a single large tubercle lies posterad of the median line dorsally. A prominent eyespot lies adjacent to the antero-dorsal junction. Hingement typical of the genus.

Dimensions : Holotype : length $0.45 \mathrm{~mm}$; height 
$0.20 \mathrm{~mm}$; biconvexity $0.18 \mathrm{~mm}$.

Occurrence: Black Creek only, localities G, H, I, J, and K. U.S.N.M. 129029, 129030, 129031.

Remarks: This species most closely resembles O. scorbiculata Alexander but the arrangement of the tubercles serves to distinguish this species. These specimens like $O$. cristata Alexander exhibit a radial reticulate pattern on and around the base of the tubercle.

\section{Orthonotacythere hannai (Israelsky) \\ Plate 6, Figures 3-5}

Cytheridea (?) hannai Israelsky, 1929, Arkansas Geol. Bull. 2, p. 12, pl. 2A, fig. 10.

Cytheropteron hannai (Israelsky) Alexander, 1929, Texas Univ. Bull. 2907, p. 105, Pl. 9, fig. 16.

Orthonotacythere hannai (Israelsky) Alexander, 1933, Jour. Paleontology, vol. 7, p. 200, pl. 25, fig. la-c; pl. 26, fig. 6a-b; pl. 27, fig. $14 \mathrm{a}-\mathrm{b}$.

Carapace in side view, ovate; dorsal margin straight; ventral margin convex, curving sharply upward posterad to a short thin caudate process at the postero-dorsal junction; anterior margin obliquely rounded, weakly rimmed medially with about four blunt spines below; posterior margin obliquely rounded with a thin caudate extension dorsally; carapace compressed, widest ventrally.

Surface of valve with an ill-defined anteromedian sulcus dividing valve into two subequal parts ; three strongly developed tubercles lie above and parallel to the ventral margin; a fourth well developed tubercle lies above the postero-dorsal junction; a fifth tubercle, more weakly developed, lies posterad of the anterior margin submedially; about four or five weakly developed tubercles are indiscriminately present on the valve, the most pronounced of these lying at or adjacent to the antero-dorsal angle. Surface of the valves with well developed reticulations giving a striated appearance to the ventrum. Internal features characteristic of the genus.

Dimensions: Fig. 3: length $0.61 \mathrm{~mm}$; height $0.39 \mathrm{~mm}$; biconvexity $0.37 \mathrm{~mm}$.

Occurrence: Peedee rare to common, Black Creek rare. Alexander lists this species both from
Taylor and Navarro units in Texas. Localities A, B, C, D, E, F, I, and K. U.S.N.M. 129032, 129033, 129034.

Remarks: This distinctive species is very close to $O$. cristata Alexander from the Paleocene. A comparison with the Paleocene specimens of $O$. cristata has shown the present specimens to be slightly smaller, more ovate in side view and weakly denticulate along the anterior margin; otherwise they are seemingly identical. Alexander (1934, p. 65) suggested that the stronger elevation of the tubercles on $O$. cristata was a distinguishing feature. In the present study the strength and tuberculate pattern of the Cretaceous specimens seem to be identical with specimens of $O$. cristata from the Paleocene of Arkansas and Tennessee.

\section{Orthonotacythere tarensis Brown, n. sp. Plate 6, Figures 1, 2}

Carapace small, oblong to quadrate in side view ; dorsal margin straight; ventral margin convex; anterior margin broadly and evenly rounded; posterior margin less broadly rounded, weakly caudate dorsally. Anterior margin broad and compressed.

A broad, shallow, weakly defined sulcus, slightly anterad of median, extends from dorsal margin to midpoint. Surface discretely tuberculate. Anterad of sulcus dorsally, a low rounded tubercle; a second low tubercle above and adjacent to postero-ventral junction; two weak tubercles above and parallel to the dorsal margin posterad. Median and ventral portions of valve with about ten fine parallel striations, strongest parallel to ventro-lateral border. Entire surface very finely reticulate. Hingement that of the genus.

Dimensions : Holotype: length $0.66 \mathrm{~mm}$; height $0.27 \mathrm{~mm}$; biconvexity $0.25 \mathrm{~mm}$. Fig. 2: length $0.71 \mathrm{~mm}$; height $0.24 \mathrm{~mm}$; biconvexity $0.23 \mathrm{~mm}$. Occurrence: Black Creek only, localities G, H, I, J, and K. U.S.N.M. 129035, 129036.

Remarks: Female dimorphs, generally broader in relation to length, seem to show stronger tubercular development. This species bears some resemblance to Monoceratina trinodosa Alexander from the Weno of Texas. 
Genus Cytherura Sars, 1866

Cytherura glossensis Brown, n. sp.

Plate 6, Figures 18, 19

Carapace small, spindle-shaped to ovate; dorsal margin faintly convex; ventral margin sinuous; anterior margin obliquely rounded; posterior margin angular, elongate caudal process slightly above middle.

A fine ridge commences in the anterior ventral area extends above and parallel to the ventral margin bends inward at the postero-ventral junction and forms a distinct open loop on the posterior third; a short weak ridge extends medially from the anterior margin, bifurcates atop the anterior slope and dies out antero-medially. Surface reticulate as a fine mesh arranged in about seven large weakly defined depressions. Internal features characteristic of the genus.

Dimensions: Holotype: length $0.42 \mathrm{~mm}$; height $0.18 \mathrm{~mm}$; biconvexity $0.14 \mathrm{~mm}$.

Occurrence: Rare to common in lower Peedee and in the Black Creek, localities A, C, F, G, H, I, J, and K. U.S.N.M. 129037, 129038.

\section{Genus Eucytherura Müller, 1894 Eucytherura curta (Jennings) \\ Plate 6, Figures 20, 21}

Cythereis curta Jennings, 1936, Bull. Am. Paleontology, vol. 23 , no. 78 , p. 52, pl. 7 , figs. $4 \mathrm{a}-\mathrm{b}$.

Carapace small, thick; quadrate in lateral view ; dorsal margin straight; ventral margin straight to slightly concave medially, concealed by overhang medially; dorsal and ventral margins con- verge posterad; anterior margin broadly rounded; posterior margin more sharply rounded, extended below in a blunt subdorsal caudate process.

Surface of valves reticulate; a ventral ridge commences medially at the anterior margin swings backward to the ventral margin posterad of the antero-ventral junction, outlines and partly conceals the ventral margin from above, swings inward at the postero-ventral junction, and passes into the valve above the posterior margin ventrally; a second ridge commences just dorsad of the first, extends backward medially to a subdued subcentral nodose process, turns obliquely, and extends backward to a point above the posterior margin dorsally; a third ill-defined ridge extends from the nodose process to the outer margin just anterad of a small glassy eye tubercle lying at the antero-dorsal junction. Short, eccentrically-arranged ridge-like projections normal to the main ridges give the carapace a coarsely reticulate appearance.

Hinge in right valve consists of an anterior pointed tooth and postjacent socket with an elongate carved crenulate tooth located at the posterodorsal junction, the terminal teeth being connected by a faintly crenulate interterminal groove formed of the dorsal marginal edge. Hinge of the left valve the counterpart of the right valve. Line of concrescence and inner margin widely separated. Valves rugose internally.

Dimensions: Fig. 20 : length $0.47 \mathrm{~mm}$; height $0.23 \mathrm{~mm}$.

Occurrence: Peedee only, localities A, B, C, D, E, and F. U.S.N.M. 129039, 129040.

Remarks: The shape, hingement, and nature of the carapace places this species in the genus Eucytherura Müller. 


\section{References}

Alexander, C. I., 1929 Ostracoda of the Cretaceous of North Texas: Texas Univ. Bull. 2907, pls. $1-9$, p. 1-134.

1932, Sexual dimorphism in fossil Ostracoda: Am. Midland Naturalist, v. 13, no. 5, p. 302-310.

1933, Shell structure of the ostracode genus Cytheropteron, and fossil species from the Cretaceous of Texas: Jour. Paleontology, v. 7 , p. 181-214.

1934, Ostracoda of the genera Monoceratina and Orthonotacythere from the Cretaceous of Texas: Jour. Paleontology, v. 8, p. 57-67.

1934, Ostracoda from the Midway (Eocene) of Texas: Jour. Paleontology, v. 8, pls. 32-35, p. 206-237.

1936, Ostracoda of the genera Eucythere, Cytherura, Eucytherura, and Loxoconcha from the Cretaceous of Texas: Jour. Paleontology, v. 10, p. 689-694.

Berry, E. Willard, 1925, Upper Cretaceous Ostracoda from Maryland: Am. Jour. Sci., 5th ser., v. 9, p. 481-487.

Blake, C. H., 1931, Notes on Ostracoda: Jour. Paleontology, v. 5, p. 160-163.

Conrad, Timothy A., 1871, Points connected with the Cretaceous and Tertiary of North Carolina (letter excerpt) : Am. Jour. Sci., 3rd ser., v. 1, p. 468-469.

Cornuel, J., 1846, Description des Entomostracés fossiles du terrain crétacé inferieur du Départment du Haute-Marne: Soc. Géol. France Mém., ser. 2, t. 1, pt. 2, p. 193-205.

Coryell, H. N., Sample, C. H., and Jennings, P. H., 1935, Bairdoppilata, a new genus of Ostracoda, with two new species: Am. Mus. Novitates, 777.

Harris, R. W., and Jobe, B. I., 1951, Microfauna of basal Midway outcrops near Hope, Ark.: Div. Geology, Arkansas Res. and Devel. Comm., Little Rock.

Howe, H. V., 1934, The ostracode genus Cytherelloidea in the Gulf Coast Tertiary: Jour. Paleontology, v. 8, p. 29-34.

Howe, H. V., and Garrett, Julius B., 1934, Louisiana Sabine Eocene Ostracoda: Louisiana Dept. Cons. Geol. Bull. 4.
Israelsky, Merle C., 1929, Upper Cretaceous Ostracoda of Arkansas: Arkansas Geol. Survey Bull. 2, app., p. 1-20.

Jennings, P. H., 1936, A microfauna from the Monmouth and basal Rancocas groups of New Jersey: Bull. Am. Paleontology, v. 23, no. 78, p. 1-76.

Jones, T. R., 1849, A monograph of the Entomostraca of the Cretaceous formation of England: Palaeontographical Soc. London, mon. v. 3 , pt. 1, p. 1-37.

Jones, T. R., and Hinde, G. C., 1890, A supplementary monograph of the Cretaceous Entomostraca of England and Ireland: Palaeontographical Soc. London, mon., v. 43, p. 1-70.

Kerr, W. C., 1875, North Carolina Geol. Survey Rept., vol. 1, p. 149.

Kline, V. H., 1943, Clay County fossils: Mississippi Geol. Survey Bull. 53.

Morrow, A. L., 1934, Foraminifera and Ostracoda from the Upper Cretaceous of Kansas: Jour. Paleontology, v. 8, p. 186-205.

Munsey, Gordon C., Jr., 1953, A Paleocene ostracode fauna from the Coal Bluff Marl member of the Naheola formation of Alabama: Jour. Paleontology, v. 27, p. 1-20.

Murray, Grover, 1938, Claiborne Eocene species of the ostracode genus Loxoconcha: Jour. Paleontology, v. 12, p. 586-595.

Murray, Grover, and Hussey, Keith M., 1942, Some Tertiary Ostracoda of the genera Alatacythere and Brachycythere: Jour. Paleontology, v. 16, p. 164-182.

Puri, Harbans S., 1953, The Ostracode genus Trachyleberis and its ally Actinocythereis: Am. Mid. Naturalist, v. 49, pp. 171-187, pl. $1,2$.

Sars, G. O., 1926, An account of the Crustacea of Norway, v. 9, Ostracoda: Bergen Mus., Bergen.

Schmidt, Ruth A. M., 1948, Ostracoda from the Upper Cretaceous and lower Eocene of Maryland, Delaware, and Virginia: Jour. Paleontology, v. 22, p. 389-431.

Sexton, J. V., 1951, The ostracode Cytherelloidea in North America: Jour. Paleontology, v. 25, p. 808-816.

Sohn, I. G., 1954, Paleocene Ostracoda from outcrops in Maryland: Science, v. 119, no. 3097, p. 656 . 
Spangler, W. B., 1950, Subsurface geology of the Atlantic Coastal Plain of North Carolina: Am. Assoc. Petroleum Geologists Bull., v. 34, p. 100-132.

Stephenson, L. W., and others, 1912, The Coastal Plain of North Carolina (Cretaceous part) : North Carolina Geol. and Econ. Survey, v. III, p. 73-171.

1923, Cretaceous formations of North Carolina: North Carolina Geol. and Econ. Survey, v. 5, p. 1-59.

Stephenson, M. B., 1936, Shell structure of the ostracode genus Cytheridea: Jour. Paleontology, v. 10, p. 695-703.

1937, Middle Tertiary Ostracoda of the genus Cytheridea: Jour. Paleontology, v. 11 , p. $145-159$.

1938, Lower Eocene Ostracoda of the genus Cytheridea from Alabama: Jour. Paleontology, v. 12, p. 570-585.

1946, Weches Eocene Ostracoda from Smithville, Tex.: Jour. Paleontology, v. 20, p. 297-344.

Swain, F. M., 1948, Ostracoda in Cretaceous and Tertiary subsurface geology: Maryland Dept. Geology, Mines, Water Res., Bull. 2, p. 187212.

1951, Ostracoda from wells in North Carolina, pt. 1, Cenozoic Ostracoda: U. S. Geol. Survey Prof. Paper 234-A.
1952, Ostracoda from wells in North Carolina, pt. 2, Mesozoic Ostracoda: U. S. Geol. Survey Prof. Paper 234-B.

Swain, F. M., and Peterson, James A., 1952, Ostracodes from the upper part of the Sundance formation of South Dakota, Wyoming, and Southern Montana: U. S. Geol. Survey Prof. Paper 243-A.

Sylvester-Bradley, P. C., 1948, Bathonian ostracodes from the Boueti bed of Langton Herring, Dorset: Geol. Mag., v. 85, no. 4, p. 185204.

1948, The ostracode genus Cythereis: Jour. Paleontology, v. 22, p. 792-797.

Triebel, E., 1938, Protocythere and Exophthalmocythere, zwie neue Ostracodengattungen aus der deutschen Kreide: Seneckbergiana, bd. 20, p. $179-200$, pls. $1-3$.

1940, Die Ostracoden der deutschen Kreide: Seneckbergiana, bd. 22, p. 160-227.

Van den Bold, W. A., 1946, Contribution to the study of Ostracoda: Doctoral dissertation, Utretch University, Amsterdam, p. 1-167.

Vanderpool, H. C., Fossils from the Trinity group (lower Comanchean) : Jour. Paleontology, v. 2, p. 95-107.

Van Veen, J. E., 1936, (1) Die Cytheridea der Maastrichter Tufkreide und des Kunrader Korallenkalker von S. Limburg: Naturalist Maandblad, Jaarg. 24, nos. 2-9. 
Species

Alatacythere alata atlantica (Sehmidt)

Bairdia pittensis $\mathrm{n}$.

Bairdoppilata pondera Jennings

Bairdoppilata postextensa (Swain)

Brachycythere raleighensis $\mathrm{n}$. $\mathrm{sp}$.

Brachycytherc ledifforma (Israelsky)

Brachycythere sphenoides (Reuss)

Brachycythere nausiformis Swain

Brachycythere rhomboidalis (Berry)

Brachycythere plena Alexander

Cytheridea (H.) monmouthensis Berry

Cytheridea (H.) ulrichi (Berry)

Cytheridea ( $H$.) fabaformis (Berry)

Cytheridea (H.) councilli $\mathrm{n}$. sp.

Cytheridea (H.) plummeri Alexander

Cytheridca (H.) sarectaensis n. sp.

Cytheridea $(H$.$) carolinensis n$.

Cytheridea (H.) wilmingtonensis $\mathrm{n}$. $\mathrm{sp}$.

Cytheridea (H.) punctura (Schmidt)

Cytheridea (C.) oblongus n. sp.

Cytherideis mayeri (Howe and Garrett)

Cytherella sp.

Cytherella bullata Alexander

Cytherella tuberculifera Alexander

Cytherella ovata (Roemer)

Cytherella herricki $\mathrm{n}$. sp.

Cytherelloidea (?) cuneiforma n. sp.

Cytherelloidea swaini $\mathrm{n}$. sp.

Cytherelloidea sohni $\mathrm{n}$. sp.

Cytherelloidea andrewsi $\mathrm{n}$. sp.

Cytherelloidea greenensis $\mathrm{n}$. sp.

Cytherelloidea inflata $\mathrm{n}$. sp.

Cytheropteron (C.) penderensis $\mathrm{n} . \mathrm{sp}$.

Cytheropteron ( $E$.) strailis $\mathrm{n}$. sp.

Cytheropteron (E.) striatum n. sp.

Cytherura glossensis n. sp.

Eucytherura curta (Jennings)

Loxoconcha neusensis n. sp.

Loxoconcha seraphae $\mathrm{n}$. sp.

Monoceratina biloba Schmidt

Orthonotacythere sulcata $\mathrm{n}$. sp.

Orthonotacythere hannai (Israelsky)

Orthonotacythere tarensis $\mathrm{n}$. $\mathrm{sp}$.

Platyeythere is costatana angua (Schmidt)

Protocythere paratriplicata Swain

Progonocythere casweliensis n. sp.

Trachyleberis bassleri (Ulrich)

Trachyleberis communis (Israelsky)

Trachyleberis gapensis (Alexander)

Trachyleberis pidgeoni (Berry)

Trachyleberis (?) praecursora n. sp.

Velarocythere arachoides (Berry)

Velarocythere cacumenata n. sp.

Velarocythere eikonata n. sp.

Velarocythere legrandi n. sp.

Velarocythere scuffeltonensis n. sp.

Key to symbols used in ehart

A-abundant, more than 25 specimens.

$\mathrm{C}$-common, more than 15 specimens.

VR-very rare, less than 5 specimens.

$\mathrm{X}$-denotes occurrence in subsurface samples from water wells.

Average sample 500 grams.
$\mathrm{R}$-rare, 5 or more specimens.

\section{PEEDEE LOCALITIES}

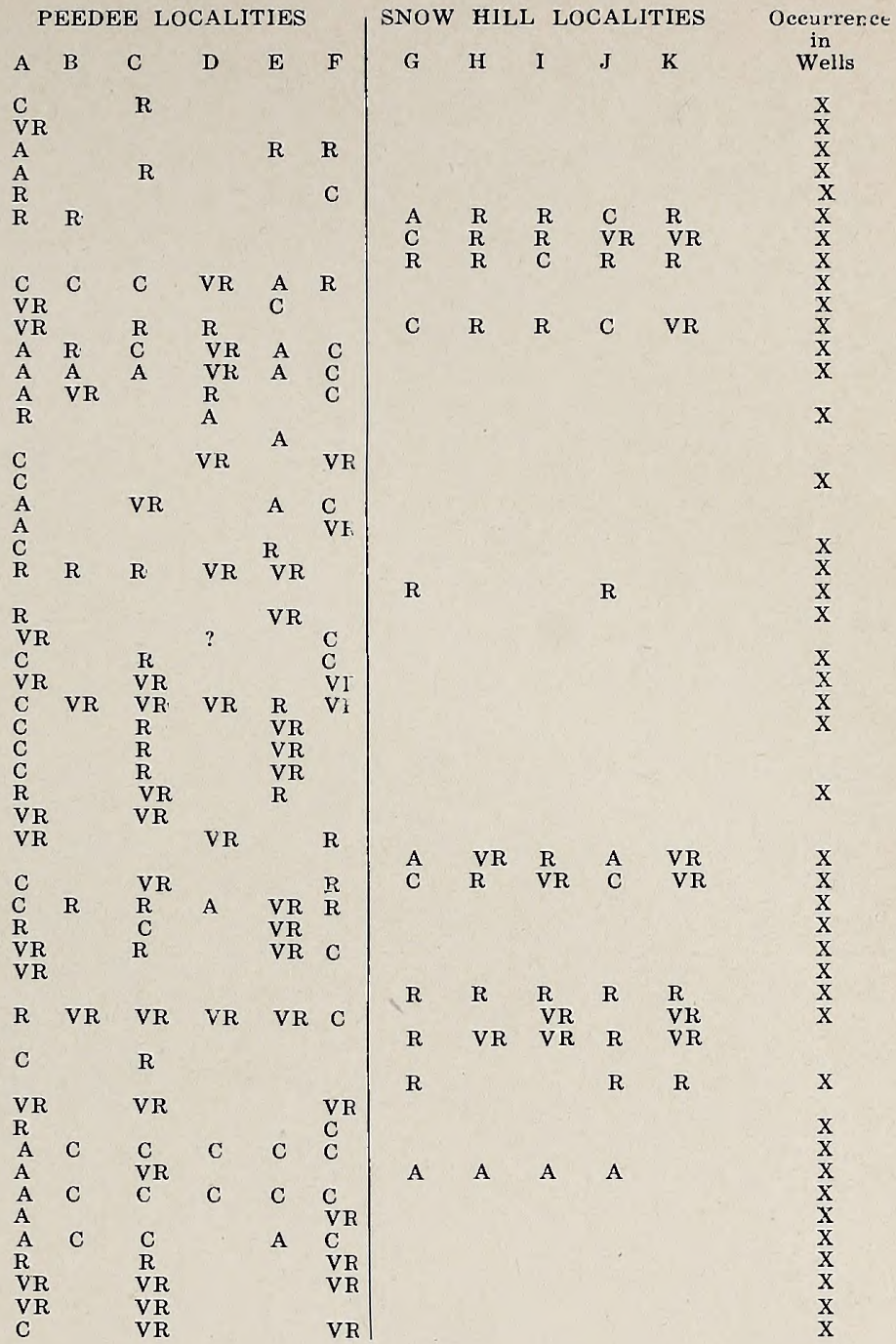

Figure 2. Checklist denoting occurrence and abundance of specimens in outcrop and occurrence of specimens in water wells. 



\section{Plates 1-7}




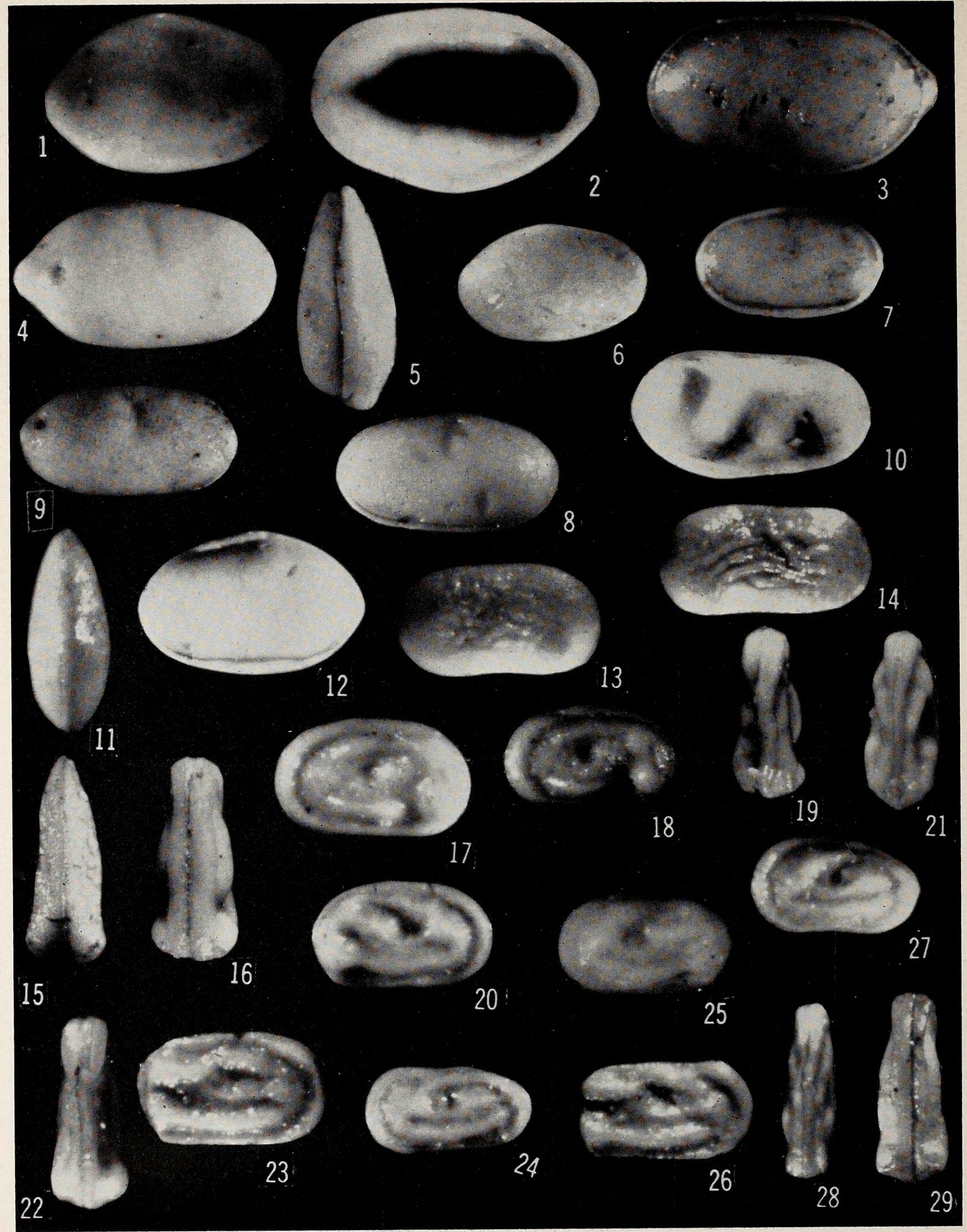




\section{Plate 1}

Figures

1-2. Cytherella sp. (p. 8)

1. Right valve, exterior, x 55, Loc. B, U.S.N.M. 128897

2. Right valve, interior, $\mathrm{x}$ 61, Loc. A, U.S.N.M. 128898

3-5. Cytherella tuberculifera Alexander (p. 7)

3. Left side view, complete specimen, $\mathrm{x}$ 63, Loc. A, U.S.N.M. 128890

4. Right valve, exterior, x 60, Loc. A, U.S.N.M. 128891

5. Dorsal view, complete specimen, $\mathrm{x}$ 54, Loc. A, U.S.N.M. 128892

6-7. Cytherella bullata Alexander (p. 7)

6. Right side view, complete specimen, $x$ 50, Loc. J, U.S.N.M. 128887

7. Left side view, complete specimen, $x$ 52, Loc. G, U.S.N.M. 128888

8-11. Cytherella herricki Brown, n. sp. (p. 8)

8. Left side view, holotype, $\mathrm{x}$ 56, Loc. A, U.S.N.M. 128893

9. Right side view, paratype, $\mathrm{x}$ 54, Loc. A, U.S.N.M. 128894

10. Left valve, interior, $\mathrm{x}$ 62, Loc. C, U.S.N.M. 128895

11. Dorsal view, paratype, x 52, Loc. A, U.S.N.M. 128896

12. Cytherella ovata (Röemer) ( $p .7$ )

Left side view, complete specimen, female, $x 55$, Loc. F, U.S.N.M. 128889

13-15. Cytherelloidea (?) cuneiforma Brown, n. sp. (p. 8)

13. Left side view, paratype, $x$ 56, Loc. A, U.S.N.M. 128902

14. Right side view, holotype, $x$ 59, Loc. A, U.S.N.M. 128903

15. Dorsal view, paratype, $\mathrm{x}$ 57, Loc. C, U.S.N.M. 128904

16-19. Cytherelloidea swaini Brown, n. sp. (p. 8)

16. Ventral view, holotype, $\mathrm{x}$ 63, Loc. A, U.S.N.M. 128899

17. Left side view, holotype, $\mathrm{x} 60$, Loc. A, U.S.N.M. 128899

18. Left side view, paratype, $x$ 57, Loc. E, U.S.N.M. 128900

19. Dorsal view, paratype, $x$ 56, Loc. A, U.S.N.M. 128901

20, 21, 25. Cytherelloidea inflata Brown, n. sp. (p. 10)

20. Right side view, holotype, x 66, Loc. E, U.S.N.M. 128914

21. Dorsal view, paratype, x 65 , Loc. E, U.S.N.M. 128915

25. Left side view, paratype, $x$ 64, Loc. E, U.S.N.M. 128916

22, 23, 26, 29. Cytherelloixea greenensis Brown, n. sp. (p. 9)

22. Dorsal view, paratype, x 63, Loc. A, U.S.N.M. 128908

23. Right side view, holotype, $x$ 63, Loc. A, U.S.N.M. 128909

26. Right side view, paratype, $\mathrm{x} 60$, Loc. A, U.S.N.M. 128910

29. Ventral view, holotype, $\mathrm{x}$ 62, Loc. A, U.S.N.M. 128909

24, 27, 28. Cytherelloidea andrewsi Brown, n. sp. (p. 9)

24. Left side view, paratype, male, $\mathrm{x}$ 59, Loc. C, U.S.N.M. 128911

27. Left side view, holotype, female, $x$ 55, Loc. A, U.S.N.M. 128912

28. Dorsal view, paratype, male, x 61, Loc. C, U.S.N.M. 128913 


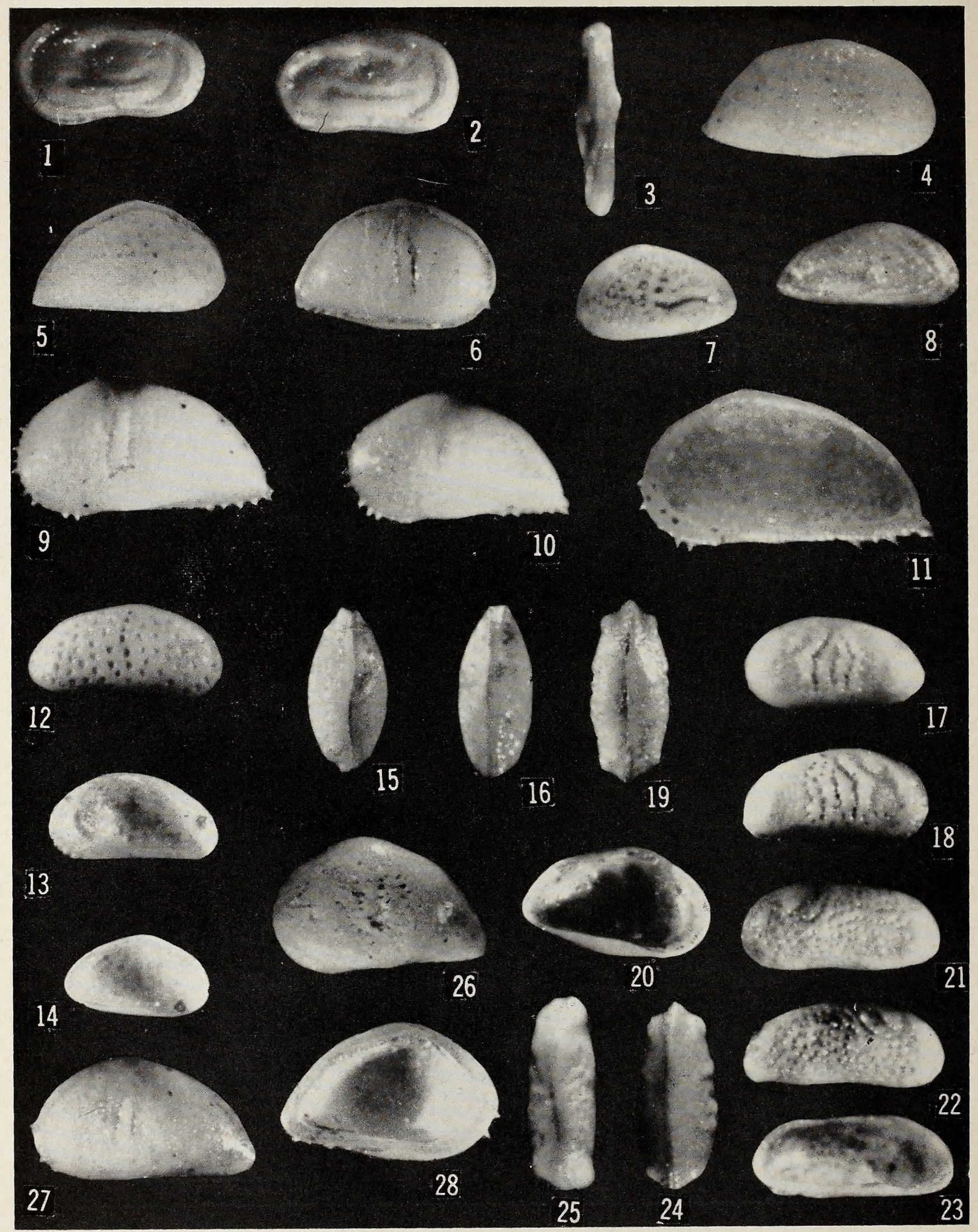




\section{Plate 2}

Figures

1-3. Cytherelloidea sohni Brown, n. sp. (p. 9)

1. Left side view, paratype, x 59, Loc. A, U.S.N.M. 128905

2. Right side view, holotype, x 59, Loc. A, U.S.N.M. 128906

3. Dorsal view, left valve, x 62, Loc. A, U.S.N.M. 128907

4-5. Cyther dea (Haplocytheridca) ulrichi (Berry) (p. 18)

4. Right valve, male specimen, x 65, Loc. A, U.S.N.M. 128985

5. Right side view, female specimen, $x$ 56, Loc. D, U.S.N.M. 128986

6. Cytheridea (Haplocytheridea) monmouthensis Berry (p. 19)

Right side view, female specimen, x 55, Loc. J, U.S.N.M. 128994

7-8. Cytheridea (Haplocytheridea) fabaformis (Berry) (p. 17)

7. Left valve, female specimen, x 50, Loc. E, U.S.N.M. 128966

8. Right valve, male specimen, $x$ 48, Loc. E, U.S.N.M. 128967

9-11. Cytheridea (Haplocytheridea) plummeri Alexander (p. 18)

9. Left valve, male specimen, $x$ 72, Loc. D, U.S.N.M. 128976

10. Left valve, female specimen, x 55, Loc. D, U.S.N.M. 128977

11. Interior view, right valve, male, $\mathrm{x} 69$, Loc. A, U.S.N.M. 128978

12-16. Cythcridea (Haplocytheridea) councilli Brown, n. sp. (p. 17)

12. Right side view, holotype, x 62, Loc. A, U.S.N.M. 128971

13. Right valve, interior, $x$ 55, Loc. F, U.S.N.M. 128972

14. Left valve, interior, $x$ 52, Loc. F, U.S.N.M. 128973

15. Dorsal view, female paratype, $x$ 58, Loc. A, U.S.N.M. 128974

16. Ventral view, male paratype, $\mathrm{x} 57$, Loc. F, U.S.N.M. 128975

17-20. Cytheridea (Haplocytheridea) carolinensis Brown, n. sp. (p. 19)

17. Left valve, paratype, x 62, Loc. A, U.S.N.M. 128987

18. Right side view, holotype, male, $\mathrm{x} 62$, Loc. A, U.S.N.M. 128988

19. Ventral view, paratype, male, x 62, Loc. A, U.S.N.M. 128989

20. Left valve, interior, female, $\mathrm{x}$ 66, Loc. A, U.S.N.M. 128990

21-25. Cytheridea (Clithrocytheridea) oblongus Brown, n. sp. (p. 19)

21. Left side view, holotype, x 63, Loc. A, U.S.N.M. 128995

22. Right side view, paratype, $\mathrm{x}$ 63, Loc. F, U.S.N.M. 128996

23. Left valve, interior, $\mathrm{x}$ 63, Loc. F, U.S.N.M. 128997

24. Ventral view, paratype, x 61, Loc. A, U.S.N.M. 128998

25. Dorsal view, paratype, x 61, Loc. A, U.S.N.M. 128999

26-28. Cytherioea (Haplocytheridea) punctura (Schmidt) (p. 19)

26. Left valve, female specimen, x 52, Loc. E, U.S.N.M. 128991

27. Left valve, male specimen, $x$ 52, Loc. E, U.S.N.M. 128992

28. Left valve, interior, $\mathrm{x}$ 50, Loc. C, U.S.N.M. 128993 


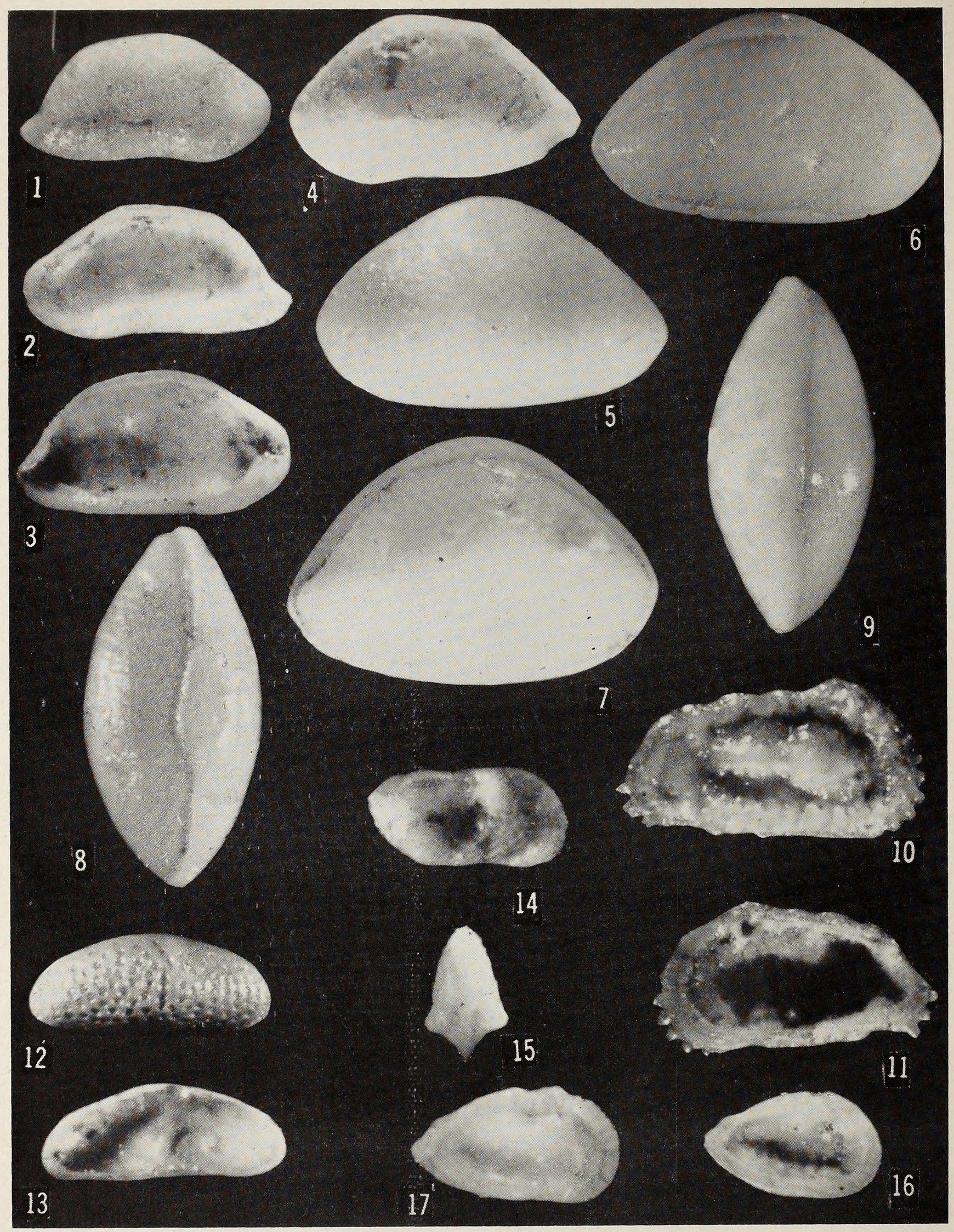




\section{Plate 3}

Figures

1-3. Bairdia pittensis Brown, n. sp. (p. 10)

1. Right valve, holotype, $x$ 76, Loc. A, U.S.N.M. 128917

2. Right valve, interior, holotype, $x$ 77, Loc. A, U.S.N.M. 128917

3. Left valve, interior, holotype, $x$ 77, Loc. A, U.S.N.M. 128917

4, 7, 8. Bairdoppilata pondera Jennings (p. 10)

4. Right valve, interior, $x$ 50, Loc. A, U.S.N.M. 128918

7. Right side view, $\mathrm{x} 60$, Loc. A, U.S.N.M. 128919

8. Ventral view, $\mathrm{x} 60$, Loc. A, U.S.N.M. 128920

5, 6, 9. Bairdoppilata postextensa (Swain) (p. 10)

5. Left side view, x 63, Loc. A, U.S.N.M. 128921

6. Right side view, $x$ 62, Loc. A, U.S.N.M. 128922

9. Dorsal view, x 65, Loc. A, U.S.N.M. 128923

10-11. Trachyleberis communis (Israelsky) (p. 14)

10. Right valve, exterior, x 81, Loc. A, U.S.N.M. 128943

11 Right valve, interior, x 77, Loc. A, U.S.N.M. 128944

12-13. Cytherideis mayeri (Howe and Garrett) (p. 23)

12. Right valve, exterior, $\mathrm{x} 63$, Loc. A, U.S.N.M. 129022

13. Right valve, interior, $\mathrm{x}$ 63, Loc. A, U.S.N.M. 129023

14-15. Monoceratina biloba Schmidt (p. 23)

14. Right valve, exterior, $\mathrm{x}$ 77, Loc. A, U.S.N.M. 129024

15. Dorsal view, molt, $\mathrm{x} 83$, Loc: This specimen is from a well (see p. 23). U.S.N.M. 129025

16-17. Protocythere paratriplicata Swain (p. 16)

16. Right side view, x 76, Loc. G, U.S.N.M. 128962

17. Left valve, interior, $\mathrm{x} 66$, Loc. J, U.S.N.M. 128963 


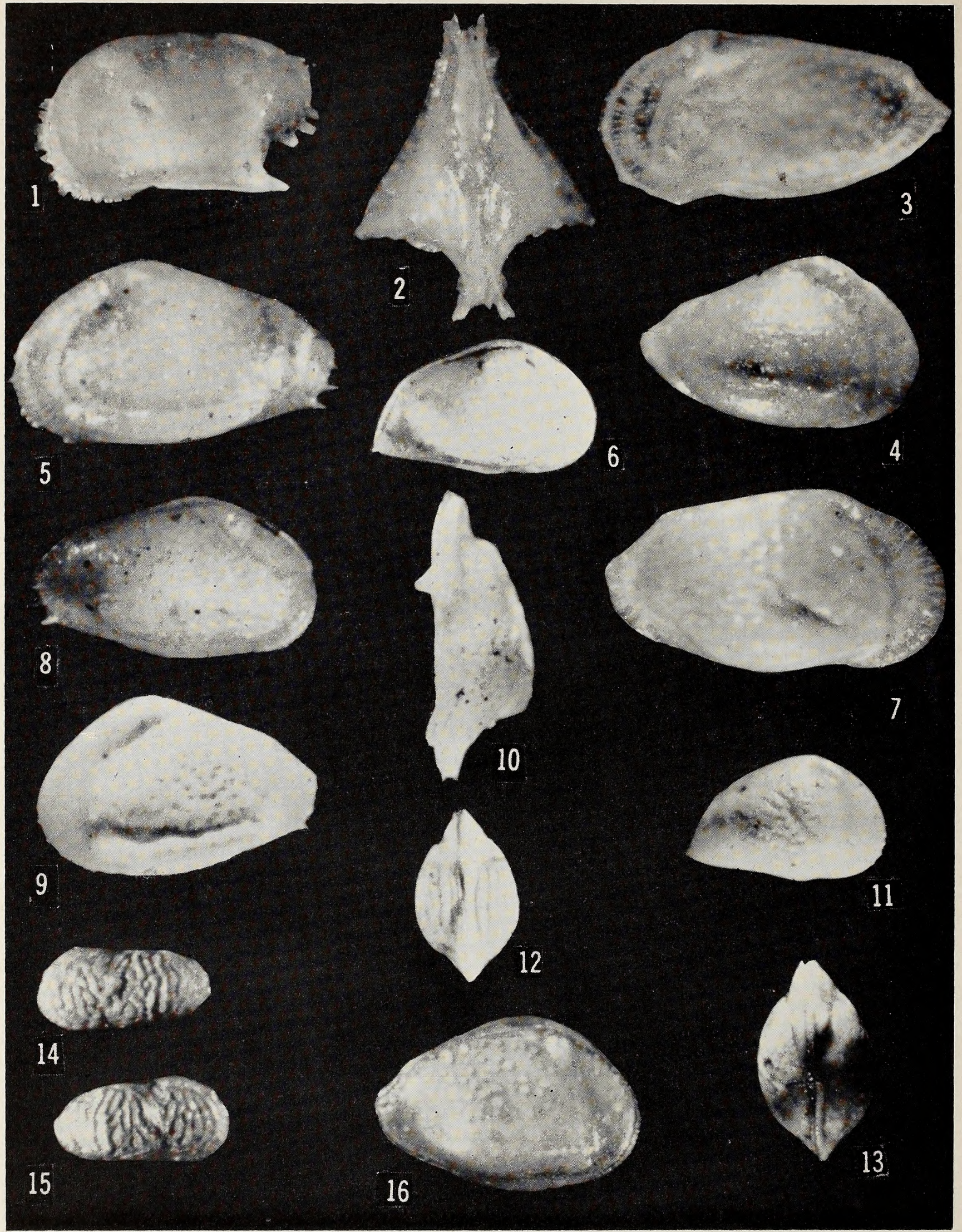




\section{Plate 4}

Figures

1-2. Alatacythere alata alantica (Echmidt) (p. 13)

1. Left valve, exterior, $\mathrm{x}$ 55, Loc. A, U.S.N.M. 128936

2. Dorsal view, complete specimen, $\mathrm{x}$ 59, Loc. A, U.S.N.M. 128937

3-4. Brachycythere nausiformis Swain (p. 12)

3. Right valve, interior, male, $\mathrm{x}$ 61, Loc. I, U.S.N.M. 128929

4. Right valve, exterior, female, $x$ 57, Loc. I, U.S.N.M. 128930

5, 8-10. Brachycythere thomboidalis (Berry) (p. 11)

5. Left valve, exterior, $\mathrm{x}$ 66, Loc. B, U.S.N.M. 128925

8. Right side view, complete specimen, $x$ 54, Loc. A, U.S.N.M. 128926

9. Exterior view, abraded left valve, $x$ 54, Loc. C, U.S.N.M. 128927

10. Dorsal view, right valve showing dentition, $\mathrm{x} 57$, Loc. E, U.S.N.M. 128928

6. Brachycythere ledaforma (Israelsky) (p. 12) Right side view, complete specimen, $\mathrm{x} 62$, Loc. H., U.S.N.M. 128932

7. Brachycythere plena Alexander (p. 12) Right valve, exterior, x 58, Loc. E, U.S.N.M. 128931

11-13. Brachycythere raleighensis Brown, n. sp. (p. 13)

11. Right side view, holotype, x 61, Loc. A, U.S.N.M. 128933

12. Ventral view, paratype, $\mathrm{x}$ 55, Loc. F, U.S.N.M. 128934

13. Dorsal view, paratype, x 63, Loc. F, U.S.N.M. 128935

14-15. Progonocytiere caswellensis Brown, n. sp. (p. 16)

14. Left valve, exterior, holotype, $\mathrm{x}$ 52, Loc. C, U.S.N.M. 128964

15. Right valve, exterior, paratype, $\mathrm{x}$ 53, Loc. C, U.S.N.M. 128965

16. Brachycythere sphenoides (Reuss) (p. 11)

Right side view, complete specimen, x 60, Loc. K, U.S.N.M. 128924 


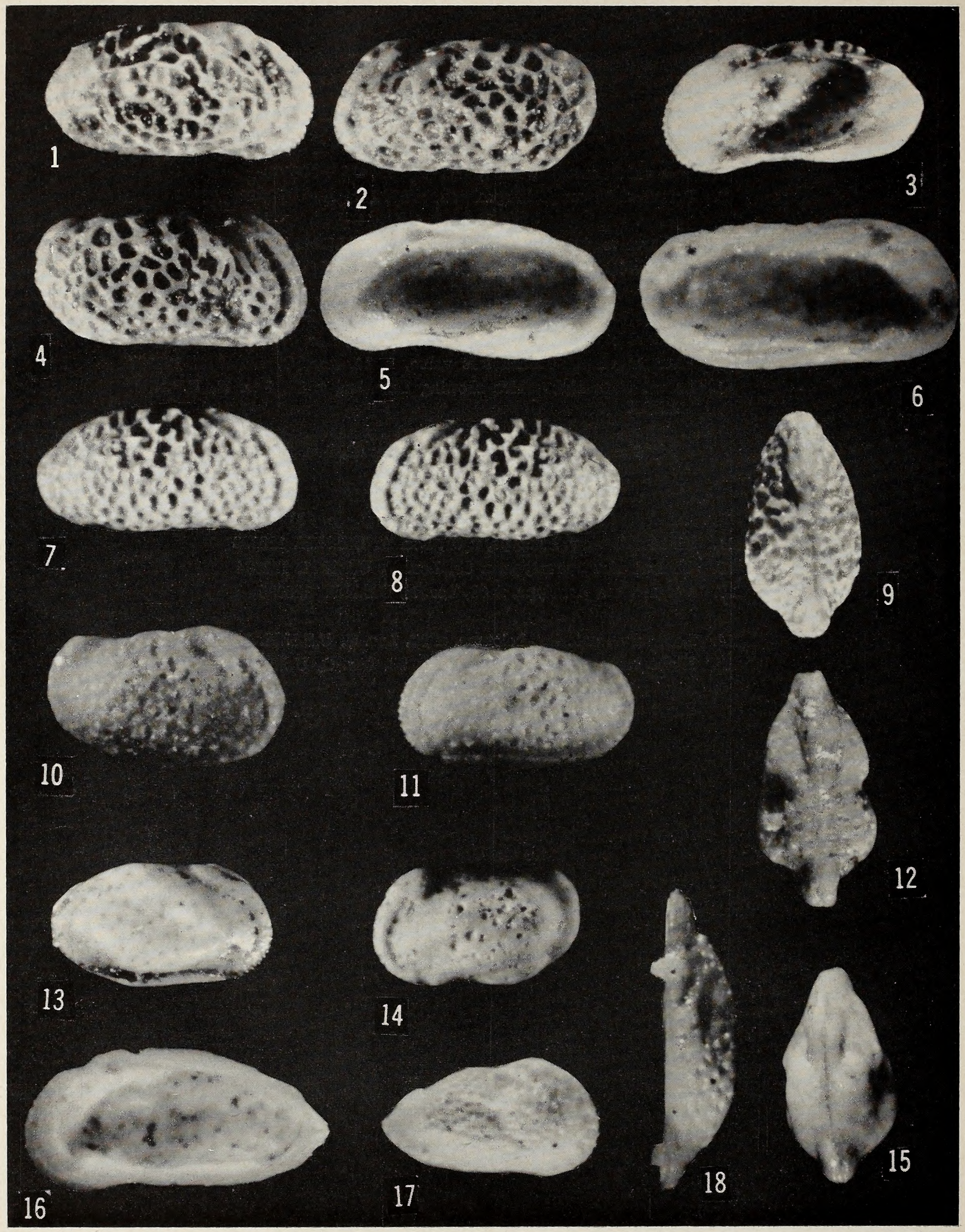




\section{Plate 5}

Figures

1-4. Velarocythere legrandi Brown, n. sp. (p. 21)

1. Right side view, holotype, $x$ 59, Loc. A, U.S.N.M. 129011

2. Left side view, holotype, $x$ 59, Loc. A, U.S.N.M. 129011

3. Right valve, interior, paratype, x 57, Loc. A, U.S.N.M. 129012

4. Right valve, exterior, paratype, x 61, Loc. C, U.S.N.M. 129012

5-9. Velarocythere scuffeltonensis Brown, n. gen., n. sp. (p. 21)

5. Right valve, interior, paratype, male, x 71, Loc. A, U.S.N.M. 129006

6. Left valve interior, paratype, male, $x$ 65, Loc. A, U.S.N.M. 129007

7. Right side view, paratype, male, $x$ 58, Loc. C, U.S.N.M. 129008

8. Left side view, holotype, female, $x$ 56, Loc. A, U.S.N.M. 129009

9. Dorsal view, paratype, $x$ 56, Loc. F, U.S.N.M. 129010

10-12. Velarocythere eikonata Brown, n. sp. (p. 22)

10. Right side view, holotype, female, $\mathrm{x}$ 66, Loc. A, U.S.N.M. 129016

11. Left side view, paratype, male, x 62, Loc. A, U.S.N.M. 129017

12. Dorsal view, paratype, $\mathrm{x}$ 64, Loc. F, U.S.N.M. 129018

13-15. Velarocythere cacumenata Brown, n. sp. (p. 21)

13. Right side view, paratype, female, $\mathrm{x}$ 66, Loc. A, U.S.N.M. 129013

14. Left side view, holotype, male, $x$ 58, Loc. A, U.S.N.M. 129014

15. Dorsal view, paratype, female, x 61, Loc. C, U.S.N.M. 129015

16-18. Velarocythere arachoides (Berry) (p. 22)

16. Right valve, interior, $x$ 77, Loc. A, U.S.N.M. 129019

17. Right side view, instar, $x$ 81, Loc. E, U.S.N.M. 129020

18. Dorsal view of right valve showing dentition, $x$ 79, Loc. A, U.S.N.M. 129021 


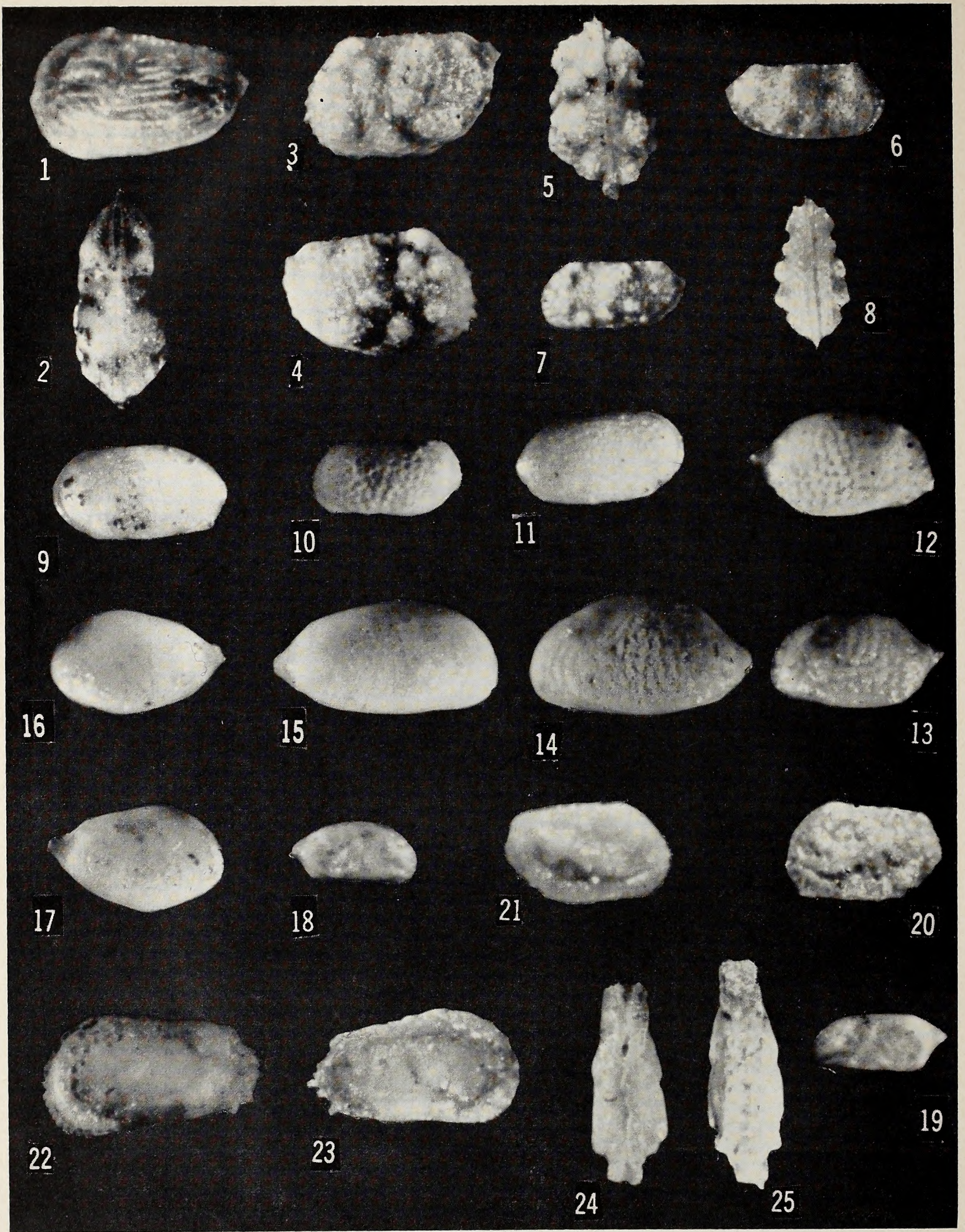




\section{Plate 6}

\section{Figures}

1-2. Orthonotacythere tarensis Brown, n. sp. (p. 24)

1. Left side view, holotype, female, x 63, Loc. I, U.S.N.M. 129035

2. Dorsal view, paratype, male, $\mathrm{x}$ 59, Loc. H, U.S.N.M. 129036

3-5. Orthonotacythere hannai (Israelsky) (p. 24)

3. Left side view, x 62, Loc. D, U.S.N.M. 129032

4. Right side view, $\mathrm{x}$ 61, Loc. D, U.S.N.M. 129033

5. Ventral view, x 59, Loc. E, U.S.N.M. 129034

6-8. Orthonotacythere sulcata Brown, n. sp. (p. 23)

6. Right valve, exterior, paratype, $\mathrm{x}$ 65, Loc. G, U.S.N.M. 129029

7. Left side view, holotype, $x$ 62, Loc. G, U.S.N.M. 129030

8. Ventral view, paratype, $\mathrm{x}$ 64, Loc. G, U.S.N.M. 129031

9, 11. Loxoconcha serarhae Brown, n. sp. (p. 23)

9. Left side view, holotype, $\mathrm{x} 63$, Loc. C, U.S.N.M. 129027

11. Right side view, paratype, $\mathrm{x} 58$, Loc. C, U.S.N.M. 129028

10. Loxoconcha neusensis Brown, n. sp. (p. 23)

Left side view, holotype, x 58, Loc. E, U.S.N.M. 129026

12-13. Cytheropteron (Cytheropteron) penderensis Brown, n. sp. (p. 20)

12. Right valve, exterior, paratype, x 66, Loc. C, U.S.N.M. 129000

13. Left valve, exterior, holotype, $\mathrm{x} 60$, Loc. A, U.S.N.M. 129001

14-15. Cytheropteron (Eocytheropteron) straillis Brown, n. sp. (p. 20)

14. Left valve, exterior, paratype, $x$ 61, Loc. D, U.S.N.M. 129002

15. Right valve, exterior, holotype, $\mathrm{x}$ 60, Loc. F, U.S.N.M. 129003

16-17. Cytheropteron (Eocytheropteron) striatum Brown, n. sp. (p. 20)

16. Left side view, holotype, female, x 66, Loc. G, U.S.N.M. 129004

17. Right side view, paratype, male, $x$ 64, Loc. K, U.S.N.M. 129005

18-19. Cythcrira glossensis Brown, n. sp. (p. 25)

18. Right side view, holotype, $x$ 59, Loc. A, U.S.N.M. 129037

19. Left side view, paratype, $x$ 57, Loc. A, U.S.N.M. 129038

20-21. Eucytherura curta (Jennings) (p. 25)

20. Left side view, $\mathrm{x}$ 63, Loc. D, U.S.N.M. 129039

21. Right side view, $\mathrm{x}$ 65, Loc. E, U.S.N.M. 129040

22-25. Platycythercis costatana angula (Schmidt) (p. 15)

22. Left side view, $x$ 59, Loc. A, U.S.N.M. 128958

23. Right side view, $x$ 55, Loc. A, U.S.N.M. 128959

24. Ventral view, $x$ 54, Loc. C, U.S.N.M. 128960

25. Dorsal view, $\mathrm{x} 61$, Loc. C, U.S.N.M. 128961 

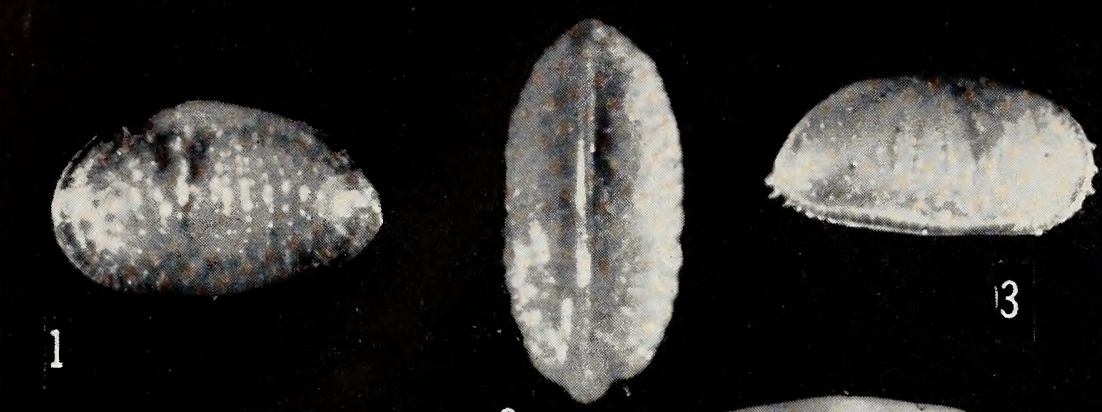

13
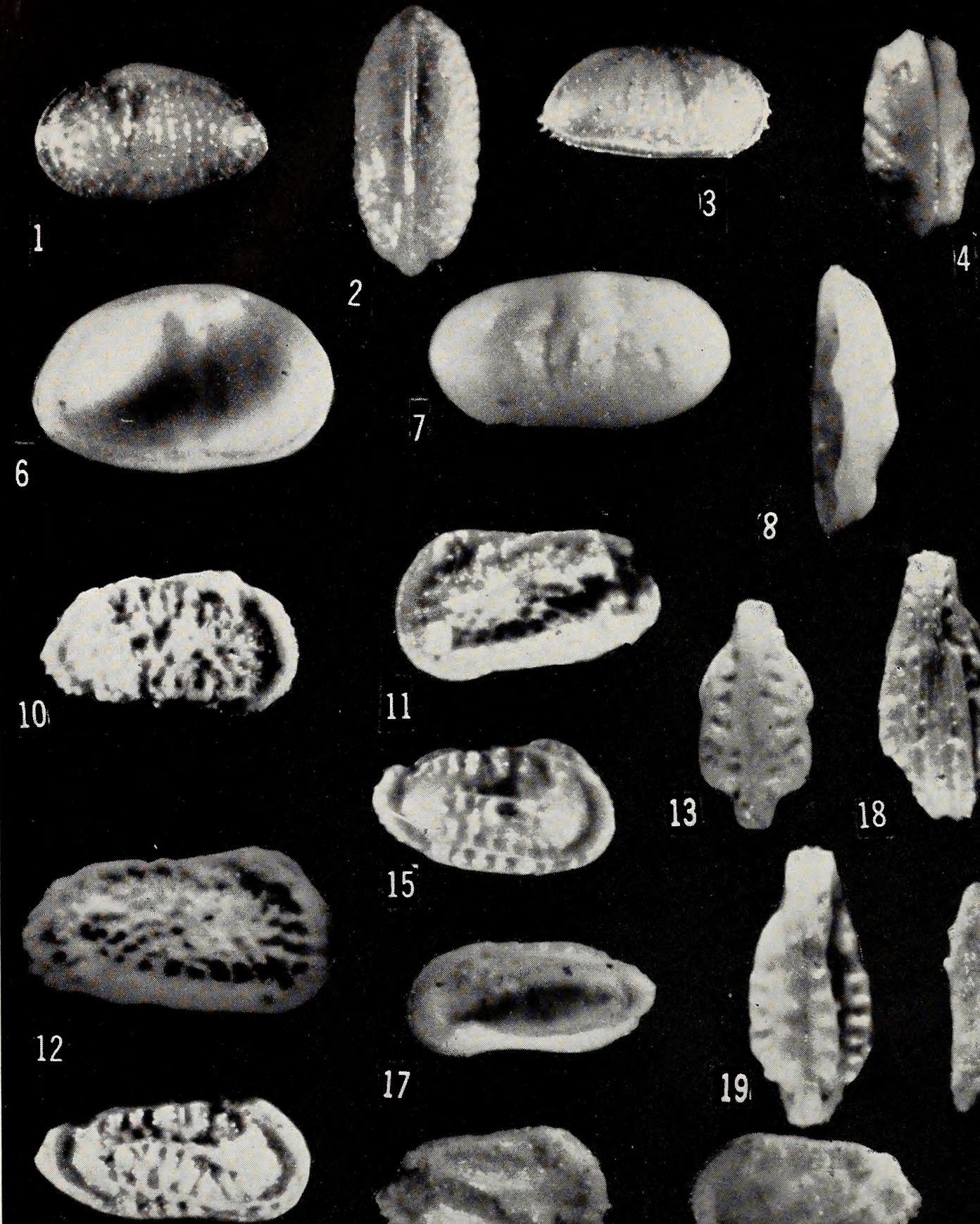
16
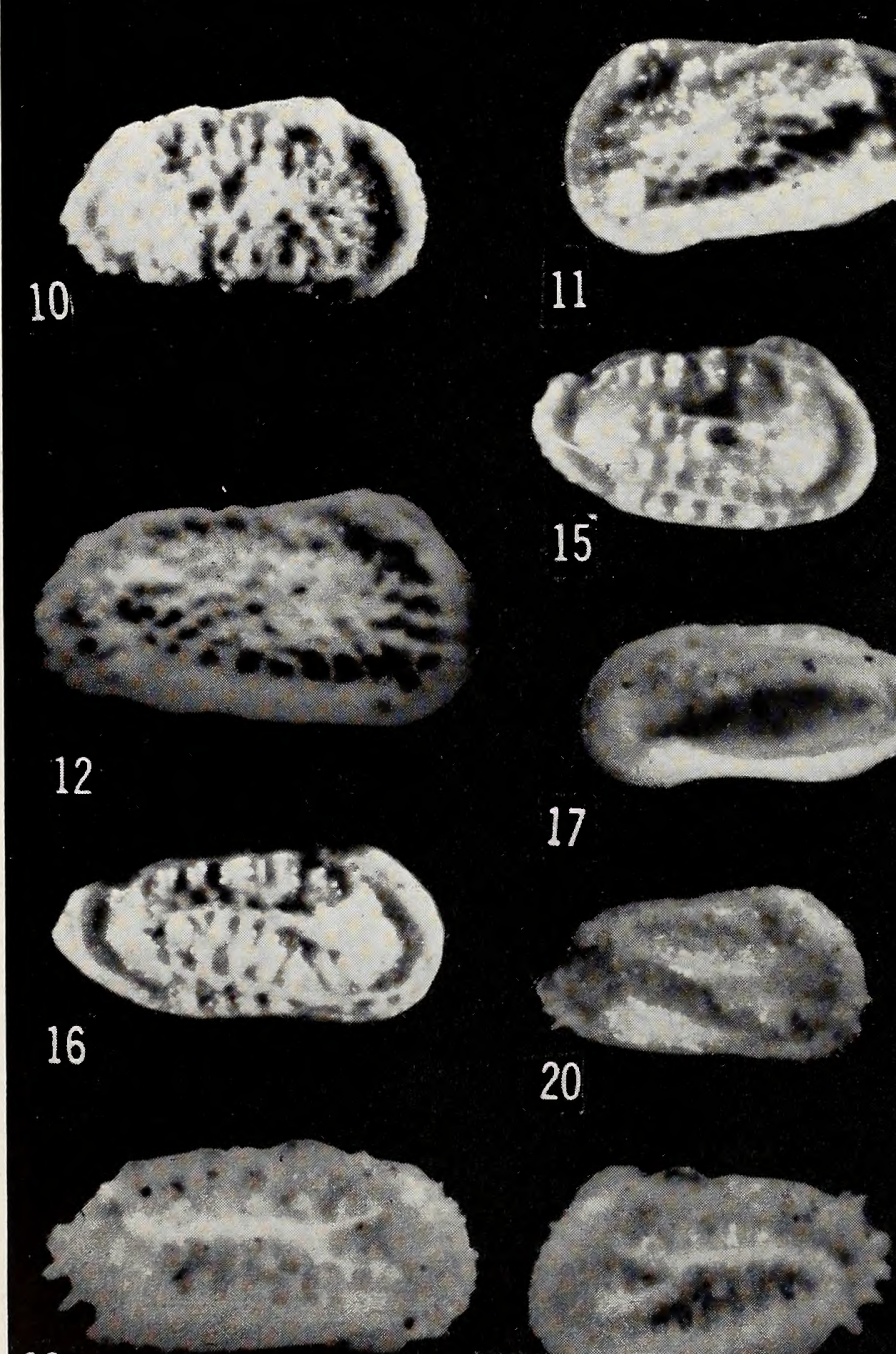

26

27

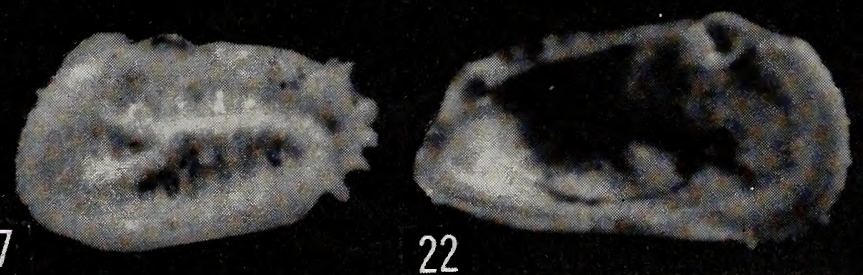

25
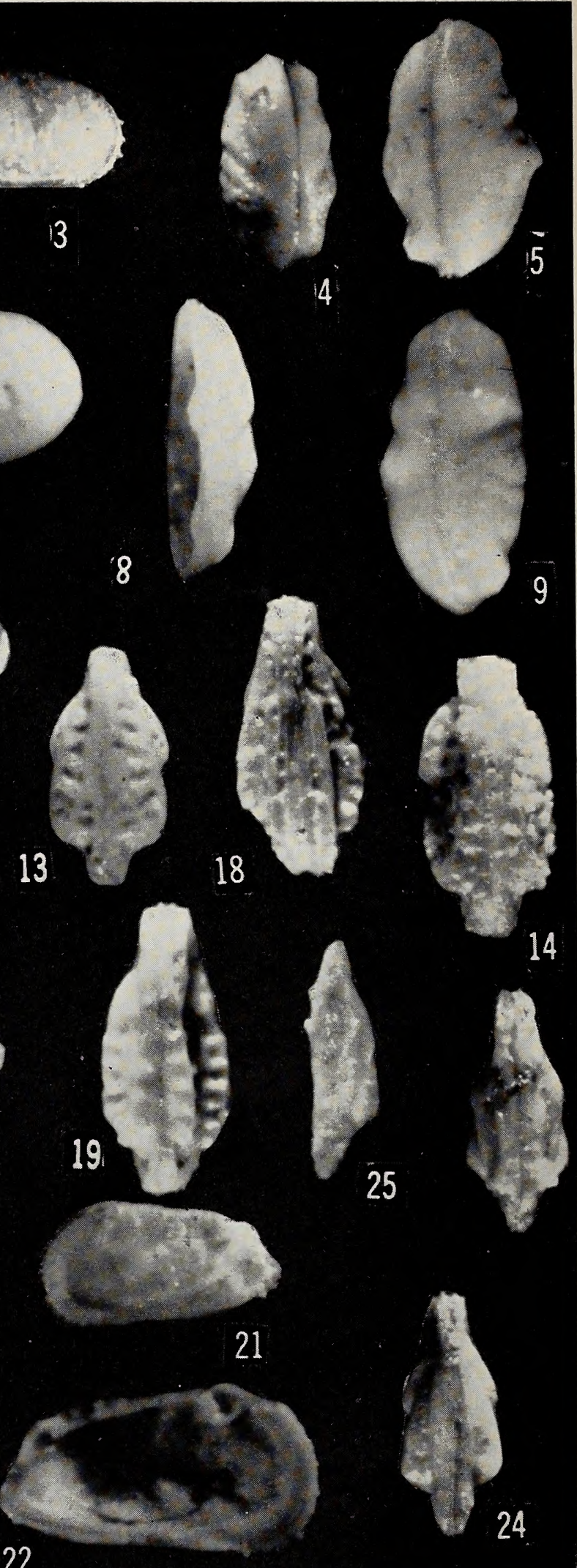


\section{Plate 7}

\section{Figures}

1-3. Cytheridea (Haplocytheridea) sarectaensis Brown, n. sp. (p. 17)

1. Left valve, exterior, female, x 53, Loc. E, U.S.N.M. 128968

2. Ventral view, holotype, x 54, Loc. E, U.S.N.M. 128969

3. Right valve, exterior, paratype, male, $\mathrm{x} 47$, Loc. E, U.S.N.M. 128970

4-9. Cytheridea (Haplocytheridea) wilmingtonensis Brown, n. sp. (p. 18)

4. Dorsal view, paratype, x 61, Loc. A, U.S.N.M. 128979

5. Ventral view, paratype, $\mathrm{x} 68$, Loc. A, U.S.N.M. 128980

6. Left valve, interior, $\mathrm{x} 67$, Loc. A, U.S.N.M. 128981

7. Left side view, holotype, $x$ 73, Loc. A, U.S.N.M. 128982

8. Dorsal view, left valve showing dentition, $x$ 73, Loc. A, U.S.N.M. 128983

9. Dorsal view, paratype, x 78, Loc. A, U.S.N.M. 128984

10-14. Trachyleberis bassleri (Ulrich) (p. 13)

10. Right valve, exterior, $\mathrm{x} 48$, Loc. F, U.S.N.M. 128938

11. Left side view, complete specimen, $\mathrm{x}$ 49, Loc. A, U.S.N.M. 128939

12. Right side view, complete specimen, $x$ 55, Loc. F, U.S.N.M. 128940

13. Ventral view, instar, $x$ 58, Loc. A, U.S.N.M. 128941

14. Dorsal view, $\mathrm{x}$ 53, Loc. F, U.S.N.M. 128942

15-19. Trachyleberis gapensis (Alexander) (p. 14)

15. Right side view, female specimen, $x$ 64, Loc. I, U.S.N.M. 128947

16. Right s.de view, male specimen, $\mathrm{x}$ 63, Loc. I, U.S.N.M. 128948

17. Right valve, interior, male, $x$ 60, Loc. I, U.S.N.M. 128949

18. Ventral view, $x$ 63, Loc. H, U.S.N.M. 128950

19. Dorsal view, $x 75$, Loc. A, U.S.N.M. 128951

20-25. Trachyleberis (?) praecursora Brown, n. sp. (p. 15)

20. Right side view, holotype, $x$ 66, Loc. A, U.S.N.M. 128952

21. Left side view, paratype, $x$ 66, Loc. F, U.S.N.M. 128953

22. Left valve, interior, paratype, $\mathrm{x}$ 68, Loc. F, U.S.N.M. 128954

23. Dorsal view, paratype, $x$ 72, Loc. A, U.S.N.M. 128955

24. Ventral view, paratype, $\mathrm{x} 67$, Loc. A, U.S.N.M. 128956

25. Dorsal view, left valve, paratype, $\mathrm{x}$ 66, Loc. A, U.S.N.M. 128957

26-27. Trachyleberis pidgeoni (Berry) (p. 14)

26. Right valve, exterior, male, $\mathrm{x} 60$, Loc. A, U.S.N.M. 128945

27. Left valve, exterior, female, $x$ 59, Loc. A, U.S.N.M. 128946 




